\title{
The Commercial Paper Market and the Securities Acts
}

Although commercial paper currently provides both a major source of financing for a diverse group of issuers and a significant investment instrument for an increasingly widespread portion of the public, it has been traditionally excluded from the full coverage of the federal securities acts. Developments in commercial paper over the last forty years have given rise to a market strikingly different from that which existed at the time these securities regulations were drafted. ${ }^{1}$ Prompted by a recent swift expansion in the volume and uses of commercial paper, along with the exposure of serious weaknesses in the commercial paper market, ${ }^{2}$ this comment undertakes a reappraisal of the relationship between commercial paper and the regulatory pattern of the securities acts.

The first section of this comment will examine the scope and opera-

1 For historical accounts of the commercial paper market, see N. BAXTER, THE CoMmercial Paper Market (2d ed. 1966); R. Foulke, The Commercial Paper Market (1931); A.O. Greef, The Commercial Paper house in the United States (1938); R. Selden, Trends and Cycles in the Commerclat Paper market, National Bureau of Economic Research, Occastonal Paper 85 (1963); Steiner, The Commercial Paper Business, 1921 FED. REs. BuLL. 920.

2 Commercial paper had been an important source of short-term business funds in the late nineteenth and early twentieth centuries, but its importance then began to decline. Johnston, Rebirth of Commercial Paper, 1968 Monthly Rev. FED. Res. BANK SAN FRANCISCo 137; see N. BAXTER, supra note 1, at 4-23. In 1933, the commercial paper market averaged only about $\$ 139$ million in commercial paper outstanding, $i d$. at 17 , table I-1, while total corporate debt stood at $\$ 76.9$ billion, 1972 Economic REPORT OF THE PRESEENT 268, table B-62. Even with its renewed growth after World War II, the 1920 peak in outstandings of approximately $\$ 1$ billion, N. BAxTER, supra note 1 , at 17 , table I-1, was not regained until 1951, $1955 \mathrm{Fm}$. REs. BuLl. 42. Corporate debt, however, had risen during that period from $\$ 57.7$ billion, U.S. DEP'T OF COMMERGE, STATISTICAI HISTORY of THE UNITED STATES 644, ser. X 428 (1960), to \$162.5 billion, 1972 Economic REPoRT OF THE President 268, table B-62. As recently as 1960, commercial paper outstanding totaled only $\$ 4.5$ billion, 1964 FED. RES. BULL. 72, in a corporate credit market of $\$ 302.8$ billion, 1972 Economic Report of the President 268, table B-62. During the 1960 s and early 1970 , commercial paper attained renewed significance as a credit instrument, when it was increasingly used by borrowers as a supplement to sometimes scarce, and often costly, bank credit. At the market's peak in May, 1970, commercial paper outstanding amounted to $\$ 39.6$ billion, FED. RES. BuLl., July, 1970, at A 37, while corporate debt for 1970 was \$774.1 billion, 1972 Economic REPORT OF THE PRESIDENT 268, table B-62. As of February, 1972, the volume of outstandings was $\$ 32.25$ billion, FED. REs. Butr., Apr., 1972, at A 33. The weaknesses in the commercial paper market that have concurrently developed are discussed in the text at notes 75-127 infra. 
tion of the contemporary market in commercial paper, with special attention to its evolution during this century. The second and third sections will focus on the treatment of commercial paper under the Securities Act of 1933 and the Securities Exchange Act of 1934, ${ }^{3}$ respectively, and will evaluate this regulatory scheme in light of current market realities. ${ }^{4}$ The thesis presented is that the commercial paper presently in use is a significantly different instrument from the paper that existed when the securities laws were enacted and that the federal regulatory treatment of commercial paper should therefore be reconsidered. ${ }^{5}$

\section{The Commercial Paper Market}

Commercial paper consists of unsecured, short-term promissory notes issued by sales and personal finance companies; by manufacturing, transportation, trade, and utility companies; and by the affiliates and subsidiaries of commercial banks. ${ }^{6}$ The notes are payable to the bearer

3 Securities Act of 1933, 15 U.S.C. $\$ \S 77$ a et seq. (1970); Securities Exchange Act of 1934, 15 U.S.C. $\$ \S 78$ a et seq. (1970).

4 There has been no analysis in the literature of this relationship. In the legal writing on securities regulation, commercial paper has never been specifically treated in depth; in the discussions of commercial paper in business journals, it has always been assumed that such paper is excluded from the full coverage of the securities acts. See, e.g., Armour, Out of the Storm Cellar, Barron's, June 21, 1971, at 3; Cloos, A Larger Role for Commetcial Paper, J. CoM. BANK LENDING, Apr., 1969, at 2, 13; Trends in Commercial Paper, SURVEY CuRRENT Bus., Sept., 1970, at 4.

5 Much of the information on the commercial paper market set forth in this comment is based on interviews conducted between August, 1971, and February, 1972 with representatives of institutions participating in all phases of the market. Many interviewees requested total anonymity; those who did not include the following: (l) commercial paper dealers: A. G. Becker \& Co. (New York); First Boston Corporation (New York); Goldman, Sachs \& Co. (Chicago); Merrill Lynch, Pierce, Fenner \& Smith, Inc. (New York); (2) direct issuers of commercial paper: Irving Trust Company (New York) (which issues paper through its holding company, Charter New York Corporation); Walter Heller \& Company (Chicago); (3) regulatory bodies: Federal Reserve Bank of Chicago; Federal Reserve Bank of New York; Securities and Exchange Commission (Washington, D.C.); (4) law firms: Chapman \& Cutler (Chicago); Ettelson, O'Hagan, Ehrlich \& Frankel (Chicago); Pollack \& Singer (New York). Information received during interviews is cited to this footnote generally because in most cases the interviewees requested total or partial anonymity.

6 Until the late nineteenth century, commercial paper was comprised largely of trade notes received by manufacturers, wholesalers, or jobbers in payment for merchandise. R. SELDEN, supra note 1, at 1. By 1931, commercial paper denoted short-term (maturity from two to nine months) negotiable instruments. It consisted of the following types of instruments in the estimated proportions: (1) unsecured, single-name promissory notes of commercial and industrial concerns (fifty percent); (2) promissory notes of commercial and industrial firms bearing the indorsement or guarantee of the officers or of other principal parties at interest (thirty percent); and (3) obligations of finance companies, cotton dealers, cattle loan companies, grain elevators, and warehouse companies, which were represented by collateral trust notes, and two-name paper-that is, notes receivable 
on a stated maturity date. Maturities range from one day to nine months, but most paper carries an original maturity between thirty and ninety days. When the paper becomes due, it is generally rolled over-that is, reissued-to the same or a different investor at the market rate at the time of maturity. ${ }^{7}$

Commercial paper notes are of two types, discount notes without interest and nondiscount notes with interest. Their face denominations range from approximately $\$ 2,500$ to $\$ 1$ million or more. Placement of commercial paper is made either directly with the investor by the issuer (direct paper) or indirectly through a dealer who in most cases acts as principal (dealer paper). Because the notes are unsecured, the issuers have generally consisted of large, well-known companies whose financial positions have been assumed to be above question. Largely because of the financial reputation of these issuers, commercial paper has been considered relatively riskless, bearing interest rates just above those on Treasury bills and bankers' acceptances. ${ }^{8}$ Funds received from the issuance of commercial paper have traditionally been used to finance current operational business expenditures of a well-defined seasonal or periodic nature. The underlying theory is that during the short period from the date of the paper's issuance to its maturity, the borrower will complete a cycle in which the cash obtained at the beginning of the transaction is transformed into commodities through the process of manufacture and sale and then converted back into cash at the end of the transaction through the collection of the proceeds of the sale. In a successful cycle, the completion of the operation that gave rise to the loan provides the funds for retiring the paper, thus rendering it self-liquidating. ${ }^{9}$

and trade acceptances bearing the indorsement of the seller (twenty percent). R. FoukkE, supra note 1, at 3, 7; see N. BAXTER, supra note 1, at 2-7. Single-name paper, or straight paper, represents those notes that are the obligations of one party only-that is, the maker. Although two or more names may appear on a note either as makers or endorsers, it is still considered single-name paper if the names represent identical interests. F.L. Garcia, Encyclopedia of BANRing AND Finance 687 (6th ed. 1962). Two-name paper includes those notes and trade acceptances that have two signatures, each representing separate interests responsible for payment. R. Foulke, supra note 1, at 7; F.L. Garcta, supra at 748; see C. Phillips, Bank CREDIT 262-63 (1926). A collateral trust note is a note secured by receivables assigned to a trustee. N. BAXTER, supra note 1 , at 9 n.13.

7 Address by John F. McGillicuddy, President, Manufacturers Hanover Trust Company, Annual Finance Conference of the American Management Association, May 19, 1971, at 18 (copy on file at The University of Chicago Law Review); Interviews, supra note 5.

8 Armour, supra note 4, at 6. For March, 1972, the rate on prime commercial paper with maturity from four to six months was 4.17 percent, while the rate on prime bankers' acceptances of ninety days was 3.95 percent, and the market yield on three-month Treasury bills was 3.72 percent. FED. REs. BuLL., Apr., 1972, at A 35.

9 C. WhitTLESEY, MONEY AND BANKING 119 (1954); Steiner, supra note 1, at 924. See also text at notes 181-92 infra. 


\section{A. The Issuers: Direct Paper and Dealer Paper}

Commercial paper is issued primarily to reduce borrowing costs; it serves as a relatively low-cost alternative to bank loans ${ }^{10}$ and as a flexible financial instrument that can be sold with little difficulty in the amounts and maturities required. In addition, by having its notes offered, the corporation receives exposure to the financial community, which is an important benefit in securing further financing. ${ }^{11}$ The significant drawback for the issuer is that commercial paper, unlike bank loans, cannot be paid before maturity at the option of the borrower. ${ }^{12}$

1. Direct Paper. Direct placement-that is, the sale of notes by the issuer without a dealer's assistance-was initiated in 1920 by a salesfinance company, General Motors Acceptance Corporation. It remained the only direct issuer until two other finance companies entered the direct placement market in $1934 .{ }^{13}$ Beginning in the middle and late 1930s, the use of directly placed paper expanded rapidly, both absolutely and as a percentage of commercial paper outstanding. By 1939, directly placed paper constituted 52.1 percent of outstandings. ${ }^{14}$ After World War II, increasingly large demands for consumer credit led to a rapid growth in the need for short-term funds by finance companies, which hold substantial consumer credit receivables. ${ }^{15}$ Commercial paper became most important not as a seasonal bank loan supplement issued by industrial concerns through dealers, but instead as a relatively inexpensive method for finance companies to obtain funds through direct placement. ${ }^{16}$ Then, in the late 1960 s, a new dimension was added to the market when banks began to issue direct paper through subsidiaries and affiliates in an attempt to overcome the loss of funds caused by rate ceilings on large certificates of deposit. ${ }^{17}$ By the middle

10 From the beginning of 1964 until June, 1971, the percent savings differential on commercial paper as compared with the bank prime rate has been approximately 0.93 percent. See The First Boston Corporation, Commerctal Paper (1971) (copy on file at The University of Chicago Law Review).

11 See N. BAXTER, supra note 1, at 11.

12 Cloos, supra note 4 , at 6 . For treatments of the advantages and disadvantages of commercial paper for both the issuer and the investor, see N. BAXTER, supra note 1, at 28-55; Cloos, supra note 4, at 4-8; Johnston, Commercial Paper: 1970, 1971 MONTHLY REv. FeD. REs. BANK SAN Francisco 57, 58-60.

13 These two finance companies were Commercial Credit Company and Commercial Investment Trust Financial Corporation. N. BAXTER, supra note 1, at 16. The next company to issue commercial paper directly was General Electric Credit Corporation, in 1952. R. SELDEN, supra note 1 , at 15 .

14 N. BAXTER, supra note 1 , at 19-20, table I-2.

I5 Id. at 21, 23; R. SELDEN, supra note 1 , at 84 .

16 See N. BAXTER, supra note 1 , at 15-27; R. SELDEN, supra note 1 , at 14-17, 19, 31-43.

17 If banks issue commercial paper directly, the funds obtained are treated as deposits and are made subject to the Federal Reserve System's reserve requirements and interest 
of 1970 , the twenty-nine nonbank direct issuers ${ }^{18}$ and the more than forty banks in the direct placement market ${ }^{19}$ accounted for approximately sixty-five percent of the total volume of commercial paper outstanding. ${ }^{20}$

Direct issuers borrow continuously in the commercial paper market in order to obtain a regular flow of funds. For the investor, direct paper is more flexible than dealer paper because direct issuers will place paper in smaller denominations and shorter maturities, tailored to the needs of the investor. ${ }^{21}$ Although denominations can range as low as $\$ 1,000$, purchases in amounts below $\$ 25,000$ are not common..$^{22}$ To justify the sizable initial expenditure necessary for the direct placement of paper, it is estimated that the issuing corporation must continuously have outstandings in excess of $\$ 200$ million. ${ }^{23}$ In practice, only the larger finance companies ${ }^{24}$ and the affiliates and subsidiaries of the larger commercial banks ${ }^{25}$ have both the operational size to utilize the substantial amounts of funds generated on a continual basis and the reputation needed to justify the credit standing essential for investors' acceptance. ${ }^{26}$ Since mid-1970, the importance of commercial paper for

rate ceilings under Regulations $\mathrm{D}$ and $\mathrm{Q}$. Commercial paper issued by bank affiliates, however, was free from rate ceilings and reserve requirements until September, 1970. Commercial banks borrow in the commercial paper market through subsidiaries and affiliates such as holding companies. The affiliates then channel the proceeds to their associated banks through purchases of loans from bank portfolios. Schadrack \& Breimyer, Recent Developments in the Commercial Paper Market, 52 MoNTHLy REv. FED. REs. BanK N.Y. 280, 286-88 (1970).

18 Johnston, supra note 12 , at 60 .

19 Amour, Beautiful Balloon?, BARRon's, May 18, 1970, at 11, 20.

20 See FED. REs. BuLL., July, 1971, at A 33.

21 Id. at 281; R. SEIDEN, supra note 1 , at 42. Another way in which direct issuers tailor their paper to the needs of the investor is the "master note agreement." Under this type of agreement, some finance companies have standing arrangements with trust departments of banks to sell paper in blocks for allocation among individual trust accounts. In effect, these are I-day obligations that are constantly renewed with adjustments of amounts outstanding and rates of interest, most commonly the posted rate on 180-day paper. The banks assign various trust funds a portion of the total amount for a certain period, thus keeping relatively small funds fully invested. Cloos, supra note 4, at 7; Johnston, supra note 12 , at 59 .

22 Interviews, supra note 5; see Schadrack \& Breimyer, supra note 17, at 281.

23 Johnston, supra note 12, at 60 . Previous estimates had been $\$ 100$ million, Cloos, supra note 4 , at 10 , and $\$ 50$ million, Johnston, supra note 2 , at 140 . The mean amount of outstandings of direct issuers was well over $\$ 200$ million at the end of 1961, in comparison with a \$156.4 million average of dealer paper per dealer. R. SELDEN, supra note 1 , at 42.

24 Johnston, supra note 12, at 60; McGillicuddy, supra note 7, at 2.

25 Johnston, supra note 12, at 60-61.

26 In the third quarter of $1970,80.8$ percent of direct paper was issued by finance companies. The remaining 19.2 percent was issued by bank affiliates. Schadrack \& Breimyer, supra note 17 , at 282 , table I. 
banks has rapidly declined, ${ }^{27}$ while directly placed finance company paper now accounts for approximately fifty-five percent of outstandings in the commercial paper market. ${ }^{28}$

2. Dealer Paper. The unique feature of the commercial paper market boom in the late 1960s and early 1970 was the extremely rapid growth of paper issued through dealers. ${ }^{29}$ Dealer paper is offered through a small number of dealers, with six investment banking firms handling most of the issues. ${ }^{30}$ It is usually sold in denominations of one hundred thousand dollars or more, with only a few dealers selling

27 At the end of July, 1970, bank-related commercial paper had reached its peak, with outstandings amounting to $\$ 7.82$ billion, of which $\$ 6.83$ billion was placed directly and $\$ 0.99$ billion was placed through dealers. See FED. REs. BuLL., July, 1971, at A 33. As of February, 1972, it had declined to $\$ 2.15$ billion, with $\$ 1.62$ billion placed directly and $\$ 0.53$ billion placed through dealers. See FED. RES. BULL., Apr., 1972, at A 33. The sharp decline in bank-related commercial paper is the result largely of the following actions of the Board of Governors of the Federal Reserve System on August 17, 1970: (1) the imposition of a five percent reserve requirement on funds receivd by bank affiliates through the issuance of commercial paper, effective September 17, 1970; (2) the withdrawal of the authority of Federal Reserve banks to waive penalties for deficient reserves resulting from the issuance of commercial paper by bank subsidiaries; and (3) the reduction of the reserve requirement on commercial bank time deposits in excess of $\$ 5$ million from six percent to five percent, effective September 17, 1970. These controls in effect subjected bank-related commercial paper of less than thirty days maturity to demand deposit reserve requirements, and such paper of longer maturities to time deposit requirements. Schadrack \& Breimyer, supra note 17 , at 290.

28 In May, 1970, commercial paper directly placed by finance companies totaled $\$ 19.30$ billion, or forty-nine percent of the entire market. See FED. REs. ButL., July, 1971, at A 33. In February, 1972, commercial paper directly placed by finance companies totaled $\$ 17.84$ billion, or fifty-five percent of the entire market. See FED. RES. Butr., Apr., 1972, at A 33. For the proportion of commercial paper to total funds of sales finance companies, see R. SELDEN, supra note 1, at 47 , table 12. Since finance companies are major providers of consumer credit, the commercial paper market is a significant channel through which funds flow to individuals.

20 Schadrack \& Breimyer, supra note 17, at 280-83; Trends in Commercial Paper, supra note 4, at 5 . Between December, 1965 and May, 1970, directly placed nonbank paper rose from $\$ 7.2$ billion to $\$ 19.3$ billion, and the number of direct issuers increased from 22 to 28 . Johnston, supra note 12 , at 62 . During the same period, dealer paper swelled from $\$ 1.9$ billion to $\$ 14.0$ billion, and the number of nonbank issuers of dealer paper increased from about 300 to almost 550. Id. The preceding figures exclude commercial paper issued by commercial bank affiliates and subsidiaries because bank-related paper became significant only in 1969. See Fed. REs. BuLl., Jan., 1970, at A 37. As of February, 1972, direct paper outstanding was $\$ 19.46$ billion, while dealer paper outstanding amounted to $\$ 12.79$ billion. See FEd. REs. BuLL., Apr., 1972, at A 33.

30 A. G. Becker \& Co.; The First Boston Corporation; Goldman, Sachs \& Co.; Lehman Commercial Paper, Inc:; Merrill Lynch, Pierce, Fenner \& Smith, Inc.; and Salomon Brothers. The number of dealers has undergone a steady decline since 1920, when there were thirty firms in this sector of the market. Most of the reduction took place between 1927 and 1933, when the number of dealers fell from twenty-seven to thirteen. R. SErDEN, supra note 1 , at 13 . 
in amounts below twenty-five thousand dollars. ${ }^{31}$ The dealer provides the issuer with marketing advice, distribution facilities, and flexibility in entering or temporarily withdrawing from the market as business needs or interest rate considerations may suggest. In selling the paper, the dealer typically acts as principal and purchases paper for his own account from issuers. The dealer is compensated by the spread between the price at which he buys the paper from the issuer and the price that he charges the investor. The current spread is one-eighth of one percent. ${ }^{32}$ In acting as principal, the dealer assumes the risk of market fluctuations that may occur before the paper is sold..$^{33}$ While this is the traditional method, some dealers will occasionally handle the selling arrangements for an issue without buying the paper. ${ }^{34}$

About sixty percent of the paper sold by dealers in recent years has been issued by "nonfinancial corporations and others," a group composed principally of industrials and utilities. ${ }^{35}$ Finance companies account for most of the remainder of dealer paper, with bank-related commercial paper comprising only a small percentage of the dealer market. ${ }^{36}$ While the finance companies have typically been in the dealer market on a year-round basis, this was not true of the nonfinancial corporations until recently. In the past, commercial and industrial firms used commercial paper almost exclusively to meet predictable periodic needs for funds. ${ }^{37}$ Today, however, this is no longer characteristic, and a number of nonfinancial corporations are constantly in the market through the dealer mechanism. ${ }^{38}$

\section{B. The Investor}

Until the closing decades of the nineteenth century, commercial paper consisted largely of trade notes received in payment for goods, which the recipients then endorsed over to banks, their own creditors, or note brokers who in turn sold them to banks. ${ }^{39}$ In the 1920 s and 1930 s, com-

31 Johnston, supra note 12, at 58; Interviews, supra note 5; see Schadrack \& Breimyer, supra note 17 , at 281 .

32 Johnston, supra note 12, at 58; Interviews, supra note 5.

33 The cost to the dealer of financing commercial paper inventory (typically by direct loans from large banks, with the commercial paper serving as collateral) increases the risk that his costs of sale will be greater than his spread. See N. BAXTER, supra note 1 , at 52 .

34 Johnston, supra note 12, at 58 . This practice, however, is common only among the larger dealers and certain of their less credit-worthy customers. Interviews, supra note 5. 35 Schadrack \& Breimyer, supra note 17, at 282, table I.

36 Id.

37 N. BAXTER, supra note 1, at 10; R. Foulke, supra note 1, at 143-45; Schadrack \& Breimyer, supra note 17 , at 281.

38 Schadrack \& Breimyer, supra note 17, at 281.

39 R. SEIDEN, supra note 1, at 1; see N. BAXTER, supra note 1, at 2-7; note 6 supra. 
mercial paper was bought essentially as a secondary bank reserve.40 All but perhaps one percent of the paper issued wound up in the portfolios of banking institutions. ${ }^{41}$ Those mercantile concerns that did invest in commercial paper generally restricted themselves to industries that were related to their own line of business and in which they were presumably competent to judge the credit standing of the issuer..$^{42}$ It was not until the mid-1930s, after the enactment of the federal securities laws, that the nonbank investors, primarily nonfinancial corporations, began to enter the market in significant force. ${ }^{43}$ By the early 1940s, banks were no longer the major holders of directly placed paper. ${ }^{44}$

Since the early 1950s, there has been an increasing trend on the part of nonfinancial corporations to reduce their proportion of non-interestbearing demand deposits in order to put their excess funds to work in the money market to earn some return. A large volume of funds that had formerly been kept idle or in government securities has been made available for investment in the commercial paper market.45 It has been estimated that in late 1961, nonfinancial corporations held more than sixty-one percent of outstandings in the direct paper market. ${ }^{46}$ In the dealer sector, it is probable that the bulk of dealer paper was held by banks until 1957 and that only thereafter were they displaced as the major holders by nonfinancial corporations. ${ }^{47}$

The commercial paper market currently serves a diverse group of investors. Nonfinancial corporations and a wide variety of "other" investors, including colleges and universities, pension and trust funds, and foreign institutions, have clearly supplanted commercial banks as the major purchasers of paper. ${ }^{48}$ Estimates for the first three quarters of

40 The Federal Reserve Board requires member banks to hold as reserve assets an amount of uninvested funds equal to a designated proportion of their deposits. Secondary reserves are particular loans and investments with a high degree of liquidity, which may be converted into reserves if necessary without risk of material loss of principal. W. Welfing, MoNeY AND BANRing 138 (1937). Reserves may be obtained by discounting eligible secondary reserves at Federal Reserve banks. See text at notes 193-207 infra.

41 R. FoulKe, supra note 1, at 11; Steiner, supra note 1, at 923 . Between 1920 and 1938, there was probably an absolute decline in corporate commercial paper holdings. R. SELDEN, supra note 1 , at $9-10$.

42 N. BAXTER, supra note 1, at 13; R. Foulke, supra note 1 , at 11.

43 R. SELDEN, supra note 1 , at 25, 27. Probably the two major factors responsible for the entrance into the direct paper market of an increasing number of nonfinancial corporate investors were the willingness of the increasingly important finance companies to place paper with flexible maturities and the elimination of interest on demand deposits under the Banking Act of 1983. Id. at 27.

44 R. SELDEN, supra note 1 , at 27-28, table 9.

$45 \mathrm{~N}$. BAXTER, supra note 1 , at 23.

46 R. SELDEN, supra note 1 , at 25-26, chart 3.

47 Id. at 28-29.

48 Schadrack \& Breimyer, supra note 17 , at 282 , table $\mathrm{I}$. While this shift has also taken 
1970 showed that "nonfinancial corporations and others" held almost ninety percent of direct paper outstanding, with life insurance companies and commercial banks accounting for the balance. ${ }^{49}$ In the dealer sector in that same period, "nonfinancial corporations and others" held about half of the outstandings, with commercial banks and investment companies making up the remainder. ${ }^{50}$

While there can be little doubt that the current commercial paper market is dominated by institutional investors, it is apparent that individual investors are buying paper in the market to a significant extent and that diverse opportunities exist for the private investor to become increasingly involved. ${ }^{51}$ Commercial paper is available to the individual investor either through his bank, from a dealer, or from a direct issuer. As a service for their customers, banks act as agents in purchasing paper for individual accounts. ${ }^{52}$ While dealers now sell a small portion of their paper to individuals, ${ }^{53}$ such transactions are generally not substantial enough to be profitable. ${ }^{54}$ Significantly, one large commercial paper dealer has computerized its operation so that it can profitably sell paper on a retail basis in denominations as small as twenty-five thousand dollars. ${ }^{55}$ Other dealers are exploring new ways of making commercial paper attractive to private investors. ${ }^{56}$ In general, however, direct paper is more suited than dealer paper to the needs of individual investors because of its availability in smaller denominations and shorter maturities. ${ }^{57}$

The increasing attractiveness of commercial paper is explained in part by the fact that it is considered to be a low-risk investment carry-

place to a large extent in the dealer market, direct paper has long been heavily relied on by nonbank investors. $R$. SELDEN, supra note 1 , at 25 .

49 Schadrack \& Breimyer, supra note 17 , at 283 , table II.

50 Id.

51 Although there are no figures specifying the extent, it is generally acknowledged that the private investor is significantly involved in the commercial paper market. Interviews, supra note 5 .

52 R. SFLDEN, supra note 1, at 25; McGillicuddy, supra note 7, at 3. See also note 21 supra.

53 One example is the fact situation of Sanders v. Nuveen, Civil No. 70 C 597 (N.D. IIl., Nov. 18, 1970), appeals docketed, Nos. 71-1163, 71-1164, 7th Cir., Feb. 26, 1971. The dealer, John Nuveen \& Co., had sold $\$ 1.7$ million of commercial paper of a small loan company in denominations as small as $\$ 3,000$ to approximately fifty investors, many of whom were individuals. Record at 186-87. See note 111 infra.

54 Interviews, supra note 5.

$55 I d$. The dealer is Merrill Lynch, Pierce, Fenner \& Smith, Inc. Id.

56 Armour, supra note 19, at 11.

57 See text and note at note 21 supra. Recently, when the Securities and Exchange Commission attempted to prevent the direct issuance by a company of paper in small denominations, the litigation resulted in a settlement under which the company could sell notes in denominations of twenty-five hundred dollars. SEC v. Perera Co., BNA SEC. REg. \& L. REP. No. 65, Aug. 26, 1970, at A-5; see note 153 infra. 
ing a somewhat higher yield than other money market instruments. ${ }^{58}$ Although there is no secondary market in commercial paper, liquidity is provided by the wide range of maturities available to satisfy investors' needs. ${ }^{59}$ While buyers are expected to hold their paper until maturity, dealers and direct issuers will on occasion, under informal "buy-back" agreements, repurchase paper before maturity at an adjusted yield from regular customers experiencing unforeseen cash needs. Dealers may also at times attempt to find another buyer for paper on a "best efforts" basis. ${ }^{\circ 0}$ From the investor's standpoint, the unsecured nature of the paper is its principal disadvantage. ${ }^{61}$

\section{Self-Regulation in the Commercial Paper Market}

The commercial paper market has developed certain safeguards that are thought to protect participants in the market. The most institutionalized form of self-regulation is the investigation of the financial position of commercial paper issuers. ${ }^{62}$ Credit checks are made by divisions of Dun \& Bradstreet, Inc. (NCO/Moody's Commercial Paper Division) ${ }^{63}$ and Standard \& Poor's Corporation ${ }^{64}$ and by the credit departments of commercial paper houses.

58 See note 8 stpra.

69 Johnston, supra note 12 , at 58.

60 Id. at 59; Interviews, supra note 5.

61 See text and note at note 6 supra.

62 In the 1920 s and 1930 s, commercial paper was sold with a varying option period (usually ten days) during which the paper might be returned. This option period gave the purchaser an opportunity to check the credit of the issuer. R. FouLkE, supra note 1 , at 73-80; R. SELDEN, supra note 1, at 13; Steiner, supra note 1 , at 928-24.

63 NCO/Moody's Commercial Paper Division, a division of Dun \& Bradstreet's Moody's Investors Service, Inc., was until August 23, 1971 the National Credit Office, a division of Dun \& Bradstreet. MOOdY's INvestors SERvice, INc., MOOdy's INDustRLALs, Aug. 27, 1971, at 2625. NCO/Moody's rates prospective issuers in descending order of quality as "prime-1," "prime-2," "prime-3," or "not rated" and supplies credit information to its clients. Until August 23, 1971, the National Credit Office had rated prospective issuers as "prime," "desirable," "satisfactory," or "not rated." Only occasional use was made of the "desirable" and "satisfactory" categories. Wall Street Journal, Aug. 31, 1971, at 2, col. 4; Interviews, supra note 5. As of January 31, 1972, NCO/Moody's rated 651 issuers of commercial paper, a group composed of 262 industrials, 166 public utilities, 106 finance companies, 50 bank holding companies, 49 mortgage finance companies, 11 insurance companies, and 7 transportation companies. Telephone interview with an NCO/Moody's Commercial Paper Division representative, Feb. 3, 1972.

64 In 1969, Standard \& Poor's began rating commercial paper, but not until mid-1970 did it become established in the rating field. Its paper classifications range from "A-1," the highest designation, through "D-9." Loomis, The Row Over Commercial-Paper Ratings, Fortune, May, 1971, at 274; Foldessy, Buyers of Commercial Paper Often Using Firms Bond Ratings As Purchasing Guide, Wall Street Journal, Nov. 3, 1970, at 3, col. 2. For a discussion of the rating procedures of Standard and Poor's, see Harries, How Corporate Bonds and Commercial Paper Are Rated, Financtar Exrcutrve, Sept., 1971, at 30. Recently Fitch Investors Service, Inc. began rating commercial paper. Interviews, supra note 5. 
Both Standard \& Poor's and NGO/Moody's base their rating of the quality of an issuer's commercial paper on considerations such as the company's net worth, liquidity position, and recent financial performance. ${ }^{65}$ Dealers perform credit investigations on issuers for whom they place paper ${ }^{68}$ and generally distribute to their customers a brief financial analysis of each of these companies. ${ }^{67}$

Among the factors a credit investigation takes into account in appraising the financial soundness of a commercial paper issuer is the company's bank credit line. ${ }^{68}$ It has been a traditional safeguard of the market that issuers maintain some form of open bank credit line, equivaIent in amount to their commercial paper outstanding. ${ }^{69}$ These open credit lines range from informal understandings between the bank and the issuer to formal revolving credit agreements between the two parties. The line of credit is generally extended by a bank on the condition that there will be no material adverse change in the financial condition of the potential borrower. ${ }^{70}$ The theory behind these arrangements is that an issuer's bank credit line would be available to pay off maturing debt if the issuer were unable either to roll over or to refinance the notes. In practice, however, bank credit lines are far from totally reliable as a safety valve. ${ }^{71}$ When an issuer is in such financial straits that it is unable either to roll over or to pay off its maturing commercial

65 Until NCO/Moody's changed its credit procedures in mid-1970, it was widely felt that the difference between a "prime" and a "desirable" rating was mainly a matter of size. Cloos, supra note 4, at 7; Interviews, supra note 5. The "prime" category covered companies whose net worth exceeded $\$ 25$ million, while "desirable" was applied to companies whose net worth was between \$10 million and \$25 million. McClintick, The Credit Checkers, Wall Street Journal, Aug. 13, 1970, at 16, col. 4.

66 John F. Donahue, Vice President of A. G. Becker \& Co., has noted: "We don't rely on NCO [National Credit Office] or S\&:P [Standard \& Poor's] or anyone else at all in our credit judgment. ... We see many names that are rated NCO prime, that we have turned down in our credit committee." Donahue \& Hinds, The Commercial Paper Market: The Outlook for Placement in 1970, in MONEY AND THE CoRporation 85, 93 (1970).

67 These one- or two-page analyses contain information about the issuer that may include such items as the names of the company's management, the amounts and sources of bank credit lines, recent balance sheets, and ratings of commercial paper and other financial instruments. Interviews, supra note 5.

68 Harries, supra note 64 , at $34,36$.

69 Johnston, supra note 12, at 58; Loomis, The Lesson of the Credit Crisis, Fortune, May, 1971, at 141, 143; Steiner, supra note 1, at 925. An exception to this practice is found in the case of the largest corporations, typically direct issuers, whose commercial paper outstanding exceeds the amount that banks could normally cover. Johnston, supra note 12, at 58. General Motors Acceptance Corporation, whose needs in commercial paper are several billion dollars, is such an issuer. Interviews, supra note 5; see Selden, Commercial Paper, Finance Companies, and the Banks, in BANkING AND MONETARY Studies 346, table 7 (D. Carson ed. 1963).

70 McGillicuddy, supra note 7, at 16; Interviews, supra note 5.

71 See text at notes 89-92, 103 infra. 
paper, the banks can withdraw their support of the issuer's outstandings. ${ }^{2}$

The final important safeguard thought to be operating in the commercial paper market is the sophistication of the investor group. ${ }^{73}$ Presumably, this group's knowledge of the financial status of the market's issuers provides some protection against the entrance into the market of financially unhealthy issuers. The pitfall, however, is that investors in this market have tended to be more concerned with the names of the issuers and the interest rate differentials than with credit analysis. ${ }^{74}$

\section{Weaknesses in the Commercial Paper Market}

Despite the safeguards that had developed in the commercial paper market, weaknesses permeated the market's structure in the late 1960s. The earliest signals of danger in the corporate community were a rapid decline in corporate asset liquidity ${ }^{75}$ and access to credit coupled with an increasing acceptance of a large percentage of debt. ${ }^{76}$ Since the early 1960 s, the trend of United States corporations had been overwhelmingly toward more debt and more leverage and, consequently, toward capital structures that included as little equity as possible.77 During this period, the continuing large gap between corporate financing needs and internally generated funds encouraged the development of new

72 Armour, supra note 4, at 19; Interviews, supra note 5 . This may be accomplished by virtue of an informal understanding or by means of an escape clause in the case of a revolving credit agreement. Interviews, supra note 5. Russell Hanson, Vice-President of the First National Bank of Chicago, has noted: "A great deal of emphasis has been placed on full coverage of borrowings with bank lines of credit but $I$ think it well to remind ourselves that this is a hedge against a drying-up of the market only, and was never intended as a safety factor for a company that is well on its way to bankruptcy or one that has developed serious financial or operating problems." Quoted in The Commercial Paper Market in 1970, Bankers Monthly, Apr., 1971, at 26, 29.

73 Interviews, supra note 5.

74 Armour, supra note 4, at 19; Interviews, supra note 5; see text and notes at notes 99, 106, 111 infra. Some observers of the market are of the opinion that while many investors in commercial paper possess a high degree of general financial expertise, many lack familiarity with this market in particular. Interviews, supra note 5.

75 One measure of liquidity is the quick asset ratio, which is defined as the ratio of cash and United States government securities to current liabilities. While in 1960 the corporate quick asset ratio was 0.60 , it averaged 0.18 in the first three quarters of 1970 . See 1971 EConomic Report of the President 171, 287, table C-77.

76 After Penn Central, Economist, Nov. 14, 1970, supp. at xxx.

77 Loomis, supra note 69, at 141 . Total debt for United States corporations rose from $\$ 302.8$ billion in 1960 to $\$ 774.1$ billion in 1970 , an increase of over 150 percent. See 1972 Economic Report of the President 268, table B-62. Long-term debt for manufacturing companies jumped from $\$ 31$ billion to $\$ 99$ billion during the decade, with the debt-toequity ratio increasing from 0.19 to 0.32. Jallow, Companies in Bondage to Debt, Natron's Business, June, 1971, at 77 . 
sources of funds such as commercial paper. ${ }^{78}$ Heavy capital expenditure programs and high inventory accumulation reflected a rapidly expanding economy. ${ }^{79}$ Many corporations seemed determined to build new plants and assembly lines before the inflationary spiral sent their expenditures even higher. ${ }^{80}$ The advantageous rates on commercial paper caused those who would ordinarily fund their capital expenditures with long-term debt to turn to commercial paper and short-term bank loans to avoid locking themselves into onerous rates for extended periods. ${ }^{81}$ Since it was felt that the investment boom was one of the major contributors to inflation, the Federal Reserve Board in the last quarter of 1968 instituted a policy of extreme monetary stringency. ${ }^{82}$ Corporations responded by turning more strongly to the issuance of commercial paper and other short-term debt to replace long-term bank loans, which were becoming increasingly expensive and difficult to procure. ${ }^{83}$ By early 1970, this remarkable trend had produced a tremendous quantity of short-term corporate liabilities ${ }^{84}$ and a dangerously low amount of liquid assets. ${ }^{85}$ The commercial paper market had almost doubled in size within little more than a year. ${ }^{86}$

As borrowers unable to secure sufficient bank credit turned to commercial paper as a supplementary or alternative source of funds, companies added to their financial vulnerability by utilizing these borrowed short-term funds in order to finance long-term programs, a violation of one of the basic tenets of corporate finance. ${ }^{87}$ Cash flows became dangerously low, and the funds needed for mandatory repayments of longterm debt and for capital expenditures became scarce. ${ }^{88}$

78 In 1965, the difference for nonfinancial corporations between capital expenditures and internal funds was $\$ 6.2$ billion. By the third quarter of 1970, the gap had grown to $\$ 23.5$ billion. Schadrack \& Breimyer, supra note 17, at 285, table III.

79 McGillicuddy, supra note 7, at 6 .

80 After Penn Central, supra note 76.

81 McGillicuddy, supra note 7, at 7. During 1967, 1968, and early 1969, there was a significant cost advantage in favor of commercial paper as compared with bank borrowing. Schadrack \& Breimyer, supra note 17, at 283.

82 See, e.g., Snellings, The Federal Reserve System and the Commercial Paper Market, J. Com. Bank Lending, Feb., 1971, at 14, 16.

83 Davidson, Liquidity Patterns in Corporate Financing, Montrily Rev. FED. REs. Bank Richmond, May, 1971, at 2, 3; see Schadrack \& Breimyer, supra note 17, at 283-86; Snellings, supra note 82.

84 Excessive use of short-term funds limits a firm's financial flexibility during periods of economic stress and major capital expenditures. McGillicuddy, supra note 7.

85 When the Fed Won the Liquidity Battle, Business WeEr, Oct. 24, 1970, at 50.

86 In January, 1969, commercial paper outstanding amounted to $\$ 21.8$ billion. FED. REs. Butr., Mar., 1969, at A 35. In May, 1970, it was $\$ 39.7$ billion. FED. REs. Burx., July, 1971, at $\mathbf{A} 33$.

87 After Penn Central, supra note 76; McGillicuddy, supra note 7, at 10; see, e.g., Loomis, supra note 69, at 279; note 103 infra.

88 From the last quarter of 1968 until the first quarter of 1970, the cash holdings of 
One consequence of the tight-money problems of both the banks and the commercial paper issuers was the collapse of one of the market's safeguards, the bank credit lines. Whereas all outstanding paper was once backed fully by bank credit lines, by 1970 many commercial paper issuers had allowed their volumes of outstandings to rise without negotiating proportionate increases in their credit lines. ${ }^{89}$ In addition, many new companies that had entered the market did not see fit or were unable to secure lines of credit in support of their issues. ${ }^{90}$ The tightmoney situation of the banks, meanwhile, prevented allocation of funds for the traditional back-up credit lines on all outstanding commercial paper.91

The very high debt-to-equity ratios and dangerously low cash flows of a number of firms in the market in 1970, combined with the lack of bank credit lines in support of much of the paper outstanding, indicates a deterioration in the quality of commercial paper in the late 1960 s. $^{92}$ The market accepted paper from small, little-known companies that did not have the financial flexibility to obtain funds elsewhere on a reasonable basis. ${ }^{93}$ The deteriorating condition of commencial paper, however, went largely unnoticed in the surrounding inflationary and tight-money trend of the period.94 A business psychology developed that began to ignore some of the fundamentals of credit extension. ${ }^{95}$ Investors in commercial paper became so sensitive to interest rate differentials that they failed to recognize differences in the credit positions of the issuers. ${ }^{96} \mathrm{~A}$ lack of current information for investors on companies that issued paper further compounded this situation. ${ }^{97}$

nonfinancial corporations declined sharply by sixteen percent, while their ownership of government securities fell seventeen percent. Simultaneously with this drastic decline in liquid assets, current liabilities increased by twenty percent. After Penn Central, supra note 76. See also Loomis, supra note 69, at 280.

89 Loomis, supra note 69; Mellon, The Challenge from Commercial Paper, BANkERS MONTHLY, May 15, 1969, at 21.

90 McGillicuddy, supra note 7, at 10.

91 Loomis, supra note 69; Snellings, supra note 82, at 18. Prior to the commercial paper market boom of the late 1960s, banks had been quite strict about requiring coverage of paper outstanding by credit lines. In some instances, the ratio of credit to paper outstanding was as high as two or three to one. Gradually, however, coverage of paper outstanding decreased to the point at which back-up credit lines in some cases became the exception rather than the rule. Interviews, stspra note 5 .

92 Schadrack \& Breimyer, supra note 17 , at 289.

93 McGillicuddy, supra note 7 , at 10.

94 Schadrack \& Breimyer, supra note 17 , at 280.

95 McGillicuddy, supra note 7 , at 9.

$98 \mathrm{Id}$. An additional problem was that many portfolio managers were not trained from a credit viewpoint and were not closely supervised. $I d$, See also Armour, supra note 4, at 19.

97 Liquidity Fears Crease the Paper Market, Business WeEs, July 11, 1970, at 90, 94. See generally McGillicuddy, supra note 7, at 14. 
Indeed, during the late 1960s and early 1970, the view gained currency that the quality of paper was improving because large corporate issuers were entering the market at the expense of smaller borrowers. ${ }^{98}$ This view was indicative of a severe confusion of corporate size with liquidity, a confusion that masked some of the deterioration in the quality of the commercial paper issued during this period.99 This tendency was clearly in evidence in the collapse of the Penn Central Transportation Company.

The Penn Central Transportation Company, ${ }^{100}$ the nation's largest railroad and sixth largest nonfinancial corporation, received approval on June 21, 1970 to file a petition to reorganize under the Federal Bankruptcy Act. ${ }^{101}$ The Penn Central had $\$ 120$ million of domestic commercial paper outstanding when it reached the point at which its paper could no longer be sold. ${ }^{102}$ By the time the bankruptcy occurred, it had outstanding $\$ 82,530,000$ of commercial paper that it had been unable either to roll over or to refinance and that was not supported by bank credit lines. ${ }^{103}$ All of the paper had been sold by Goldman,

98 For example, in March, 1969, the National Credit Office, in discussing "the market's growing exclusiveness," said that "the ready availability of top quality paper, coupled with financial problems of a few finance companies, has tended to weed out lesser rated paper and many smaller firms have dropped out of the market." Schadrack \& Breimyer, supra note 17, at 289. At one point in mid-1970, the National Credit Office was rating the paper of 653 issuers, all but 34 of which carried a "prime" rating. McClintick, supra note 65 .

99 Schadrack \& Breimyer, supra note 17, at 289; see McClintick, supra note 65 .

100 The Penn Central Transportation Company is a wholly owned subsidiary of the Penn Central Company. J. Daughen \& P. Binzen, The Wreck of the Penn Central 207 (1971).

101 Schadrack \& Breimyer, supra note 17, at 289.

102 Hanna, Taking Heat Off the Commercial Paper Market, 212 CoM. \& Fin. Chron. 1152 (1970). By application filed September 12, 1969, as supplemented October 2, 1969, the Penn Central Transportation Company had sought authority from the Interstate Commerce Commission under section 20a of the Interstate Commerce Act to issue commercial paper in the amount of $\$ 50$ million. The company had at that time \$150 million of commercial paper outstanding. The proceeds of the new issue were to be used (1) to reimburse the company's treasury, in part for past capital expenditures and matured obligations; and (2) to replenish its cash. While granting approval of the new issue, in part because of the "strong financial condition" of the company and the tight money market, the ICC expressed concern over the Penn Central's reliance on short-term financing for long-term purposes. Noting the traditional use of short-term financing for shortterm needs, the Commission warned that as of June 30, 1969, the Penn Central had a deficit working capital situation that could be expected to worsen if short-term financing were increased. The ICC further cautioned that " $[t]$ he exhaustion of short-term credit to refinance maturing long-term debt or to finance long-term capital expenditures could expose a carrier to a serious crisis in the event of an economic squeeze, at which time a carrier may require short-term financing for traditional use." Penn Central Transp. Co. Notes, 336 I.C.C. 1, 4 (1969).

103 In 1970, the Penn Central had commercial paper outstanding of $\$ 193.4$ million. 
Sachs \& Co., the nation's largest commercial paper dealer, to approximately sixty lenders. ${ }^{104}$ That confusion of corporate size with liquidity had occurred could not be denied-the National Credit Office (now NCO/Moody's) had rated the Penn Central's commercial paper as "prime"105 until June 1, 1970.106

After the Penn Central entered reorganization, holders of paper issued by other corporations lost confidence in the commercial paper market. ${ }^{107}$ Their apprehension produced a major run on the market as nonbank paper outstanding contracted by $\$ 3$ billion, almost ten percent, in the first three weeks of July, 1970.108 Recognizing the seriousness of the run on commercial paper, ${ }^{100}$ the Federal Reserve System took decisive steps to prevent a domino effect on overall credit conditions. ${ }^{110}$

J. DAughen \& P. Binzen, supra note 100, at 256. Part of the plan to keep the railroad alive was to roll over the paper as it matured. Between April 21, 1970 and May 8, 1970, maturities and payments of commercial paper exceeded sales by $\$ 41.3$ million as a loss of confidence in the Penn Central surfaced. Part of the outstandings that matured by May 8 had been redeemed with funds obtained from a $\$ 59$ million Swiss loan, but there were still $\$ 152.1$ million in outstandings to be paid off. By June $30, \$ 75$ million of this amount was coming due. Id. at 263-64. The Penn Central also had revolving credit for $\$ 300$ million, which was used by the railroad to cover many types of debt. Id. at 230 . By approximately the end of May, 1970, the last $\$ 50$ million available was used to pay off maturing commercial paper. $I d$. at 271-72.

104 In re Penn Central Securities Litigation, 325 F. Supp. 309, 310 n.I (J.P.M.L. 1971). 105 See note 63 supra.

106 Loomis, supra note 64. See also note 65 supra. As a result, there was considerable loss of confidence in the National Credit Office. Interviews, supra note 5. For a discussion of the National Credit Office just after the Penn Central collapse, see McClintick, The Credit Checkers, Wall Street Journal, Aug. 13, 1970, at 1, col. 6. Many institutional investors soon turned to companies' bond ratings to determine what commercial paper to buy. Foldessy, supra note 64 , at 3 , col. 2; see text at note 116 infra.

107 See Loomis, supra note 69; Schadrack \& Breimyer, supra note 17, at 289; Snellings, supra note 82 , at $17-18$.

108 Schadrack \& Breimyer, supra note 17, at 289.

109 In the panic atmosphere that controlled the money markets following the Penn Central bankruptcy, large amounts of commercial paper simply could not be rolled over. For example, the outstandings of Chrysler Financial Corporation, a subsidiary of Chrysler Corporation, fell within weeks from $\$ 1.5$ billion to less than $\$ 700$ million. There was a very real danger that the commercial paper market might crumble, touching off a massive credit collapse and a chain reaction of corporate failures. See, e.g., Liquidity Fears Crease the Commercial Paper Market, BusINEsS WEEK, July 11, 1970, at 90; Loomis, supra note 69, at 143; Schadrack \& Breimyer, supra note 17, at 288-90; When the Fed Won the Liquidity Battle, supra note 85.

110 The Federal Reserve System's discount policy was temporarily liberalized in order to assure the availability of funds to banks and their customers. Banks were immediately informed that the Federal Reserve discount window would be available for increased member bank borrowings in order to enable banks to make loans to customers wishing to pay off maturing commercial paper. In addition, the Federal Reserve Board suspended interest rate ceilings on thirty- to eighty-nine-day certificates of deposit in order to provide an alternative source of financing to borrowers who were being placed in financial straits by their inability to reissue maturing commercial paper. The Commercial 
While the collapse of the Penn Central has by no means exemplified the trend among issuers of commercial paper, there have been other significant defaults on paper outstanding in the last few years. ${ }^{111}$ As a result of certain of these defaults, litigation was initiated. ${ }^{112}$ Most of the litigation has, of course, grown out of the failure of the Penn Central. ${ }^{113}$

Paper Market in 1970, supra note 72, at 27; Schadrack \& Breimyer, supra note 17, at 289; When the Fed Won the Liquidity Battle, supra note 85. Perhaps the most important instance in which the banks came to the rescue of a commercial paper issuer was the case of Chrysler Corporation, in which funds were provided by 250 banks across the country. See Loomis, supra note 69.

111 Among them are Mill Factors Corporation, a prominent name in the factoring business, which defaulted in 1969 on $\$ 6.7$ million of commercial paper outstanding, Heavy, Heavy . . . Forbes, Aug. 15, 1971, at 21, that had been sold to fifty-odd institutional investors, Heinemann, Financial Collapse and Human Tragedy Stalk Mill Factors, N.X. Times, Apr. 23, 1969, at 71, col. 1; Winter \& Hirsch, Inc., a Chicago small-loan company, which as of February, 1970 ceased to make further payments to its creditors, who included holders of $\$ 1.7$ million of commercial paper, Record at 186-87, Sanders v. Nuveen, Civil No. 70 C 597 (N.D. Ill., Nov. 18, 1970), appeals docketed, Nos. 71-1163, 71-1164, 7th Cir., Feb. 26, 1971; Pioneer Finance Company, whose commercial paper holders received approximately fifty cents on the dollar for their $\$ 3$ million in outstandings when the company ran into financial difficulties in 1966, Armour, supra note 19, at 21. See generally Heinemann, Pioneer Finance: 'Tight Money' Claims a Casualty, N.Y. Times, Sept. 26, 1966, at 63, col. 3; and Atlantic Acceptance Corporation, an important name in Canadian finance, which could not roll over several million dollars of its notes in 1965, Armour, supra note 19, at 21. See generally N.Y. Times, Dec. 12, 1969, at 89, col. 5.

112 The suit involving the default by Winter \& Hirsch is Sanders v. Nuveen, Civil No. 70 C 597 (N.D. Ill., Nov. 18, 1970), appeals docketed, Nos. 71-1163, 71-1164, 7th Cir., Feb. 26, 1971. In 1970, Goldman, Sachs \& Co. was sued by two investors for alleged damages resulting from the purchases of $\$ 2.29$ million of Mill Factors short-term notes from the firm. Denying all liability in both actions, Goldman, Sachs paid $\$ 50,000$ to the plaintiffs as part of a complex settlement. Allan, Goldman, Sachs, N.Y. Times, July 11, 1971, § 3, at 3, col. 5; Heavy, Heavy . . . , supra note 111 .

113 Approximately forty different suits with total claims of $\$ 63$ million have been initiated as a result of the sale of the Penn Central's commercial paper. The principal defendant is Goldman, Sachs \& Co., which sold the Penn Central paper. The plaintiffs in these cases alleged that they purchased short-term promissory notes of the Penn Central from Goldman, Sachs and that the paper became worthless when the petition in reorganization was subsequently filed. They further alleged that Goldman, Sachs violated federal securities laws, state business laws, and common law rights of the plaintiffs in connection with the sales of their commercial paper by misstating or omitting material information possessed by it concerning the financial health of the Penn Central. BNA SEc. REG. \& $L$. REP. No. 77, Nov. 18, 1970, at A-10; see, e.g., Complaint, Mallinckrodt Chem. Works v. Goldman, Sachs \& Co., MDL Docket No. 56A (J.P.M.L., 1971).

Goldman, Sachs \& Co. has reached an out-of-court settlement of certain of these lawsuits with claims totaling approximately $\$ 20$ million. One plaintiff reported that it had agreed to drop its claims against Goldman, Sachs in exchange for twenty percent of the face amount of the paper plus a share of any payment on the paper that the firm receives in the Penn Central's reorganization. A representative of Goldman, Sachs has said that the settlement was a business judgment made to avoid long and costly litigation and that no party to the settlement conceded any of the allegations made by other parties to the litiga- 


\section{E. The Market After Penn Central}

Since the Penn Central collapse, the commercial paper market has become a more mature financial market. ${ }^{114}$ The events of 1970 produced a concern with credit criteria that forced many of the financially weaker companies, both large and small, out of the market, thus increasing the overall quality of the market's issuers. ${ }^{115}$ The emphasis on credit standards has produced substantially revamped criteria and operating procedures in the rating services and dealer credit departments. ${ }^{116}$

Despite its improved condition, many of the rreaknesses of the commercial paper market that surfaced in mid-1970 remain as potential problems. ${ }^{117}$ While the market's list of issuers was streamlined in the wake of the Penn Central bankruptcy, issuers with poor creditability have survived. ${ }^{118}$ The continuous rollover of commercial paper, a significant deviation from the original "current transactions" nature of the market, has also persisted.119 If excessive use is made of the shortterm market in preference to longer-term financing, a firm's financial flexibility can be effectively curtailed during periods of major capital expenditure or economic stress. ${ }^{120}$

Credit analysis also still presents major difficulties for the commercial paper market. ${ }^{121}$ Although the flow of information among participants

tion. Wall Street Journal, Apr. 18, 1972, at 2, col. 2 (Midwest ed.); Wall Street Journal, Apr. 27, 1972, at 20, col. 4 (Midwest ed.). See also note 112 supra.

114 Interviews, supra note 5; see McGillicuddy, supra note 7, at 13-15. Recently, two new dimensions were added to the commercial paper market: the offering of commercial paper in Europe, known as Eurocommercial paper, Innovation, Economist, Oct. 9, 1971, at 100; and the decision of several banks to adopt a floating prime rate geared to the rate on ninety-day commercial paper, Wall Street Journal, Oct. 25, 1971, at 4, col. 4.

115 McGillicuddy, supra note 7, at 13; Interviews, supra note 5.

116 Armour, supra note 4.

117 McGillicuddy, supra note 7, at 14, 17-19; Interviews, supra note 5. See also text at notes 69-113 supra.

118 Interviews, supra note 5; see Harries, supra note 64, at 34. See also text at notes 93-99 supra.

119 McGillicuddy, supra note 7; see text at notes 9, 37-38 supra.

120 McGillicuddy, supra note 7.

121 Armour, supra note 4, at 19. See also text at notes 62-67, 95-98, 106 supra. That effective credit analysis may still be lacking in the commercial paper market was demonstrated in the debate over the credit standing of Chrysler Financial Corporation, a subsidiary of Chrysler Corporation. On March 21, 1971, a few days after the release of Chrysler Corporation's 1970 annual report, the National Credit Office withdrew the "prime" rating that it had previously assigned to Chrysler Financial. The reason given was the "unimpressive" earnings record of Chrysler Corporation. Chrysler Financial's commercial paper outstanding dropped from $\$ 1.03$ billion on March 19 to $\$ 889$ million on March 26, $\$ 758$ million on April 2, and a low of $\$ 640$ million on April 16. To meet the rapid runoff of these notes, Chrysler Financial was forced to tap its bank lines of credit. The decline was stemmed on April 16, when Chrysler's commercial paper received an " $A-3$ " 
in the market has been improved in the past year and one-half, much progress is needed in providing reliable current information about issuers in order to allow investors to make effective credit judgments. ${ }^{122}$

Further potential problems for the commercial paper market include dependence on bank credit lines for liquidity, ${ }^{123}$ excessive use of shortterm credit by issuers of commercial paper, ${ }^{124}$ failure properly to space maturities, ${ }^{125}$ reliance on size-oriented considerations in purchasing paper, ${ }^{126}$ and the lack of market experience of many portfolio managers. ${ }^{127}$

\section{The Segurities Act of 1933}

Commercial paper of the type currently in use is clearly included within the definition of a "security" in section 2(1) of the Securities Act of $1933,{ }^{128}$ and the remedies for fraud contained in sections 12(2) 129 and $17(a)^{130}$ of the Act are consequently available to the investor.

The 1933 Act prohibits the offering or sale of securities unless they

rating from Standard \& Poor's, which cited Chrysler Corporation and Chrysler Financial as good credit risks. By late June, Chrysler Financial's outstandings were $\$ 850$ million. Then, in July, 1971, the National Credit Office restored Chrysler Financial's "prime" rating. Armour, supra note 4, at 19; Heinemann, Chrysler Unit Gets Top Rating, N.Y. Times, Aug. 18, 1971, at 49, col. 4; see Loomis, supra note 64 . The credit rating war apparently ended when NCO/Moody's upgraded Chrysler Financial's rating on its new scale on February 11, 1972, see note 64 supra, and Standard \& Poor's announced that it had raised Chrysler Financial's rating from "A-3" to "A-2," Wall Street Journal, Mar. 7,1972 , at 23, col. 1 (Midwest ed.). Such a sharp controversy over the soundness of one of the country's largest corporations leaves open to serious questioning, however, the reliability of the market's credit judgments. Armour, supra note 4, at 19. See also note 109 supra.

122 McGillicuddy, supra note 7, at 14; see text and note at note 67 supra.

123 See text and notes at notes 68-72, 89-91, 103 supra.

124 See text and notes at notes 75-91 supra.

125 Since the basic theory of commercial paper is that maturities should coincide with anticipated collections, which then provide the means of retiring the paper, it is important for the borrower to space maturities over the entire available spectrum in order to avoid excessive pressures on its ability to pay. Day, Wall Street's Commercial Paper Crisis, Business MANAGEMENT, Sept., 1970, at 42; McGillicuddy, stipra note 7, at 18-19; see text at note 9 supra.

126 See text at notes 74, 99, 106 supra.

127 See text and notes at notes 74,96 supra.

12815 U.S.C. \& 77b(I) (1970). The section defines a "security" as follows:

When used in this title, unless the context otherwise requires-

. . The term "security" means any note, stock, treasury stock, bond, debenture, evidence of indebtedness, certificate of interest of participation in any profit-sharing agreement, collateral-trust certificate, preorganization certificate or subscription, transferable share, investment contract, voting-trust certificate, certificate of deposit for a security, fractional undivided interest in oil, gas, or other mineral rights, or, in general, any interest or instrument commonly known as a "security," or any certificate of interest or participation in, temporary or interim certificate for, receipt for, guarantee of, or warrant or right to subscribe to or purchase, any of the foregoing.

12915 U.S.C. \& $77 l(2)(1970)$.

13015 U.S.C. \& 77q(a) (1970). 
have been properly registered with the Securities and Exchange Commission or unless either the securities themselves or the particular transaction in which they are sold are exempt from the registration requirements. ${ }^{131}$ It has been widely assumed ${ }^{132}$ that the registration provisions do not apply to commercial paper because of the exemption offered in section $3(a)(3)$ of the 1933 Act for certain promissory notes with an original maturity of less than nine months. ${ }^{133}$ Where registration is required, important legal and practical consequences result, including liabilities for untrue assertions or omissions of material fact in the registration statement, ${ }^{134}$ requirements for a satisfactory prospectus and its delivery, ${ }^{135}$ and leverage of the SEC through its power to delay or suspend the effectiveness of registration. ${ }^{136}$ Failure to register subjects both the one who offers or sells the securities and the controlling persons of the issuer ${ }^{137}$ to absolute liability. ${ }^{138}$

Due to the paucity of relevant case law, examination of the question whether the exemption from registration under section $3(a)(3)$ of the 1933 Act is applicable to commercial paper must deal in large part with legislative intent. ${ }^{139}$

\section{A. Legislative History and Securities Act Release No. 4412}

The original 1933 draft for a federal securities act provided no exemption for short-term notes. ${ }^{140}$ The section 3(a)(3) exemption of the

131 Securities Act of $1933, \S 5,15$ U.S.C. $\S 77$ e (1970). Section 5 is qualified by sections 3 and 4 of the 1933 Act, 15 U.S.C. $\$ \$ 77 c-d$ (1970). Section 3 exempts certain securities from the registration requirements of section 5 , and section 4 exempts certain types of transactions.

The commercial paper involved in the Penn Central litigation was exempt from registration by virtue of section $3(a)(6)$ of the 1933 Act, which exempts "[a]ny security issued by a common or contract carrier, the issuance of which is subject to the provisions of section 20a of Title 49 [the Interstate Commerce Act]." 15 U.S.C. $\S 77 c(a)(6)$ (1970). See also note 101 supra.

132 E.g., Gutmann, Commercial Paper, Magazine of Wall Streer, Aug. 15, 1970, at 32; Hershman, The Case for Commercial Paper, DuN's Review, June, 1968, at 27; When the Whistle Blew, Economisr, Nov. 21, 1970, at 96. See also note 4 supra.

133 I5 U.S.C. \& 77c(a)(3) (1970). The section provides for the exemption of

[a]ny note, draft, bill of exchange, or banker's acceptance which arises out of a current transaction or the proceeds of which have been or are to be used for current transactions, and which has a maturity at the time of issuance not exceeding nine months, exclusive of days of grace, or any renewal thereof, the maturity of which is likewise limited .....

134 Securities Act of 1933, § 11, I5 U.S.C. \& 77k (1970).

135 Id. § 10, 15 U.S.C. § 77j (1970).

136 Id. \& 8, 15 U.S.C. \$ 77h (1970).

137 Id. § 15, 15 U.S.C. \& 770 (1970).

138 Id. § 12(1), I5 U.S.C. § $77 l(1)(1970)$.

139 For a general discussion of the legislative history of the 1933 Act, see Landis, The Legislative History of the Securities Act of 1933, 28 GEO. WASH. L. REV. 29 (1959).

140 The draft was introduced in the House as H.R. 4314, 73d Cong., Ist Sess. (1933), and in the Senate as S. 875, 73d Cong., 1st Sess. (1933). 
1933 Act came about as a result of the prompting of certain parties, principally the Federal Reserve Board, during the committee hearings on this draft. ${ }^{141}$

In letters to the Chairmen of the House and Senate Committees, the Board's Secretary recommended an amendment to the original draft that is in substance identical to section 3(a)(3). ${ }^{142}$ The Board thought it apparent that the proposed act was "intended to apply only to stocks, bonds, debentures, and other similar securities of the kind commonly known as investment securities, which are issued for the purpose of obtaining capital funds for business enterprises and are purchased by persons for investment." 143 The amendment was suggested because it seemed to the Board that the Act was 'not intended to apply to bankers' acceptances or to short-time paper issued for the purpose of obtaining funds for current transactions in commerce, industry, or agriculture and purchased by banks and corporations as a means of employing temporarily idle funds." 144

The scope of the section 3(a)(3) exemption-the result of the Board's distinction between investment instruments and temporary instruments ${ }^{145}$-is interpreted in Securities Act Release No. 4412, an advisory opinion issued in 1961 purporting to recite the legislative history of that exemption. ${ }^{146}$ The SEC said in part:

The legislative history of the [1933] Act makes clear that §3(a) (3) applies only to prime quality negotiable paper of a type not ordinarily purchased by the general public, that is, paper issued to facilitate well-recognized types of current operational business requirements and of a type eligible for discounting by Federal Reserve banks. ${ }^{147}$

141 Hearings on H.R. 4314 Before the House Comm. on Interstate and Foreign Commerce, 73d Cong., 1st Sess. 179-83 (1933) [hereinafter cited as Hearings on H.R. 4314]; Hearings on S. 875 Before the Senate Comm. on Banking and Currency, 73d Cong., 1st Sess. 94-95, 120 (1933) [hereinafter cited as Hearings on S. 875].

142 Letter from Chester Morrill, Secretary, Federal Reserve Board, to Rep. Sam Rayburn, Apr. 3, 1933, in Hearings on H.R. 4314, supra note 141, at 180-81; Letter from Chester Morrill, Secretary, Federal Reserve Board, to Sen. Duncan U. Fletcher, Apr. 3, 1933, in Hearings on S. 875, supra note 141 , at 120.

143 Id.

$144 I d$.

145 See Hearings on H.R. 4314, supra note 141, at 181-83. The Federal Reserve Board's eligibility requirements for discounting apparently provided the basis for the Board's proposal. See Regulation A, Regulations of the Federal Reserve Board, Series of 1928, in U.S. BOARD OF GOVERNORS OF THE FEDERAL, RESERVE SYSTEM, DIGEST OF Rulings OF the FEDERAL RESERve BOARD (1914-1927, INCLUSIVE) 129-37 (1928); text and notes at notes 193-99 infra.

146 Securities Act Release No. 4412 (Sept. 20, 1961).

147 Id. 
On its face, the Release provides four criteria for determining the applicability to commercial paper of an exemption from the registration and prospectus provisions of the 1933 Act. The paper must be (1) prime quality negotiable paper, (2) issued to facilitate well-recognized types of current operational business transactions, (3) discountable at a Federal Reserve bank, and (4) of a type not intended to be marketed to the general public.

Two congressional reports issued in connection with the consideration of the Act in 1933 formed the basis of the Release. The House Report on the Act ${ }^{148}$ explains that the section 3(a)(3) exemption as finally enacted applies to "short-term paper of the type available for discount at a Federal Reserve bank and of a type which rarely is bought by private investors." 149 The Release also quotes from a Senate Report ${ }^{150}$ limiting the exemption to commercial paper that is "not intended to be marketed to the public" and that "ordinarily is not advertised for sale to the general public."151 The Release fails to point out, however, that the Senate Report was referring to a clause in the original draft of section 3(a)(3) that would have granted the exemption only "when such paper is not offered or intended to be offered for sale to the public"152 and that the 1933 Act as passed by Congress deleted that phrasing. This omission later engendered a challenge to the SEC's interpretation of the scope of section 3(a)(3). ${ }^{153}$ Nevertheless, an exam-

148 H.R. REP. No. 85, 73d Cong., 1st Sess. (1933).

149 Id. at 15. See also Hearings on H.R. 4314, supra note 141; Hearings on S. 875, supra note 141 .

150 S. REP. No. 47, 73d Cong., Ist Sess. (1933).

151 Id. at $3-4$.

152 S. 875, 73d Cong., Ist Sess. $\$ 2$ (a) (1933), as amended, 77 Conc. Rec. 2979 (1933).

153 The SEC's interpretation of the scope of the section 3(a)(3) exemption was challenged in SEC v. Perera Co., Civil No. 68-1256 (S.D.N.Y., Aug. I, 1969). BNA SEC. REG. \& L. REP. No. 65, Aug. 26, 1970, at A-5. See generally Wall Street Journal, Apr. 2, 1968, at 15, col. 3. Relying primarily on the 1961 Release, the SEC had sought a permanent injunction to prevent Perera Company, a dealer in foreign currency, from violating sections 5 (a) and $5(c)$ of the 1933 Act by failing to register commercial paper that it sold in denominations as small as one thousand dollars. $I d$. The SEC charged that the small denominations in which the paper was issued indicated that it was to be marketed to the general public and that therefore the paper could not qualify for a section 3(a)(3) exemption. In response, Perera argued that the SEC's discussion in the Release of legislative history was misleading because it failed to point out that the "general public" requirement in the Senate Report referred to a clause in the original draft of section 3(a)(3) that had been deleted in the Act as it was passed. The omission of this fact from the Release, Perera asserted, indicated that the SEC had "knowingly distributed a deceitful publication, thereby attempting to entrap corporations into committing violations of section 5 of the Act." BNA SEC. REg. \& L. REP. No. 65, Aug. 26, 1970, at A-5. Without admission by either party as to the validity of the allegations or defenses, a settlement agreement was reached on the procedure to be followed by Perera in the offer, sale, and delivery of its commercial paper. Under the compromise, Perera would avoid using any written forms 
ination of the 1933 Act offers considerable support for each of the SEC's four criteria for an exemption.

In 1931, commercial paper was essentially a very sound secondary reserve for banks. ${ }^{154}$ The dominance of single-name rather than twoname paper reflected the feeling that a firm selling commercial paper should be a prime credit risk. ${ }^{155}$ One commercial paper dealer, in a letter to the Chairman of the Senate Committee that was holding hearings on the proposed Act, described the then current practice when he wrote that commercial paper had proved to be the "prime secondary reserve" for banking institutions. In urging an exemption provision for commercial paper, in part because it was a prime investment, the dealer argued that if commercial paper had not always been considered a prime investment for banks, it would not have been eligible for discounting under the original Federal Reserve Act. ${ }^{156}$ On the basis of these considerations, the SEC appears to have asserted its prescription in the Release that commercial paper be of "prime quality" in order to be eligible for an exemption under section 3(a)(3)..$^{157}$

That the exemption applies only to paper of a type issued to facilitate well-recognized kinds of current operational business requirements is stated explicitly in the statute. ${ }^{168}$ Language substantially similar to the

of solicitations or advertisements, except for an order form that might be sent to present or former holders of its notes along with a notation that the paper was not being offered or sold pursuant to a registration statement. The order form would have to be accompanied by a copy of Perera's most recent financial statement. In addition, Perera agreed that it would not offer or sell any short-term notes in denominations of less than twentyfive hundred dollars and that the proceeds of such sales would be used principally for the purchase of foreign exchange inventory and the repayment of short-term notes at maturity. Id. Indicative of the SEC's failure to insist on the validity of its interpretation in the Release of section $3(a)(3)$ is its concession that Perera could issue notes in denominations as small as twenty-five hundred dollars with no limitation on the types of investors to whom the paper could be sold. During the litigation, the district court granted a protective order on the ground of executive privilege in order to prevent Perera from taking the deposition of the SEC official who had been ultimately responsible for the Release. SEG v. Perera Co., 47 F.R.D. 535 (S.D.N.Y. 1969).

154 R. FoulKE, supra note 1, at 68; Hearings on H.R. 4314, supra note 141, at 182; see text and note at note 40 supra.

155 N. BAXTer, supra note 1, at 9; see note 6 supra.

156 Letter from McCluney \& Co. to Sen. D. U. Fletcher, Apr. 1, 1933, in Hearings on S. 875, supra note 141, at 95; see text at notes 197-99 infra. See also R. Foulke, supra note 1 , at 6 .

157 See Securities Act Release No. 4412 (Sept. 20, 1961).

158 The specific reference is to a note "which arises out of a current transaction or the proceeds of which have been or are to be used for current transactions . . . " Securities Act of 1933, § 3(a)(3), 15 U.S.C. \& 77c(a)(3) (1970). The "current transactions" requirement is not found in the comparable provisions of other SEC statutes: Securities Exchange Act of 1934, § 3(a)(10), 15 U.S.C. § 78c(a)(10) (1970); Public Utility Holding Company Act of 1935, § 6(b), I5 U.S.C. § 79f(b) (1970); and Investment Company Act § 2(a)(36), 15 U.S.C. $\S 80 a-2(a)(36)(1970)$. 
"current transactions" phrasing of section 3(a)(3) is also found in the Federal Reserve Board's letter proposing the exemption..$^{159}$ The committee hearings contain further references to the practice of using commercial paper for "self-liquidating" transactions and "temporary purposes." 160 The requirement that the paper be discountable by a Federal Reserve bank, a concept quite similar to the "current transactions" theory as it was set forth in the Board's letter, ${ }^{161}$ is contained in the House Report on the 1933 Act. ${ }^{162}$

Although the SEC supported its fourth criterion-that the commercial paper be of a type not ordinarily purchased by the public-with the Senate Report on a bill that was not enacted, ${ }^{183}$ further examination of the legislative history provides strong evidence of the existence of such a requirement for an exemption. Statements made during the House Committee hearings exhibit an understanding that the commercial paper instrument to which the exemption was to be applied was sold only to banks and not to "the public."164 Such a qualification was expressly included in the amended Senate version of the Act, which limited the exemption to instances "when such paper is not offered or intended to be offered for sale to the public."165 In the course of the Senate debate, the exemption was amended to exclude that clause. The text of the motion to strike demonstrates that the commercial paper to which the securities legislation referred was not sold to the general public and that the original clause requiring that instruments exempted by section 3(a)(3) not be sold to the general public was deleted in order to insure that the exemption would be interpreted to include certain financial instruments, other than commercial paper, that were sold to the general public. Because commercial paper circulated only among banks, the provision in the original draft was thought to be unnecessary. ${ }^{100}$

159 See text at notes $142-44$ supra.

160 Hearings on H.R. 4314, supra note 141, at 180-81; Hearings on S. 875, supra note 141. See also text at note 9 supra.

161 See text at notes $142-44$ supra.

162 H.R. REP. No. 85, 73d Cong., Ist Sess. 15 (1933). See also Letter from McCluney \& Co. to Sen. D. U. Fletcher, supra note 156.

163 See text and notes at notes 150-53 supra.

164 Hearings on H.R. 4314, supra note 141, at 180-83; Hearings on S. 875, supra note 141.

165 S. 875, § 2(a), 73d Cong., Ist Sess. (1933), as amended, 77 Conc. REc. 2987 (1933); see note 166 infra.

16877 CoNG. REC. 2987 (1933): Mr. ADAMs. . . I move to strike out the words "when such paper in not offered or
intended to be offered for sale to the public."

The matter has been discussed with the Senator from Florida (Mr. Fletckikg) [Chairman of the Senate Committee on Banking and Currency], and it is intended to 


\section{B. The Four Criteria and the Commercial Paper Market}

When the four criteria that the SEG derived from the legislative history of section $3(\mathrm{a})(3)$ are analyzed, two points emerge. First, a significant proportion of the commercial paper currently in existence does not conform to those criteria. Second, with the exception of the requirement prohibiting sale to the "general public," the criteria no longer provide a viable basis for determining whether an exemption should be granted to a particular issue of commercial paper.

1. Prime Quality. Various dictionaries define "prime" as "first class" or "first in quality." 167 "Prime investment" has been defined as "[a] first class, gilt-edged, hi-grade investment; one considered so safe, conservative and sound, [that] dividends or interest payments are unquestioned." 168 The term "prime quality" can, therefore, be interpreted as referring to paper whose ability to bear interest and to repay debt is extraordinarily reliable.

Recent defaults on commercial paper clearly indicate that not all paper is of "prime quality."169 The current disregard of the "prime quality" concept is further demonstrated by the marketing of commercial paper that does not receive a "prime" rating. ${ }^{170}$ Moreover, reliance on such a guideline in determining whether a particular issue must be

protect from the operation of the act certain paper which should not be included along with commercial paper, since it merely circulates among banks, instead of the general public.

Mr. FLETCHER. I think it is a very good amendment.

The Presiding Officer. The question is on agreement to the amendment to the amendment.

The amendment to the amendment was agreed to.

A financial instrument that was sold to the general public in considerable amounts in the 1920s and 1930s, and that was specifically included within the exemption, is the banker's acceptance. L. Rufener, MONEY AND BANKInc IN THE UNITED STATES 309, 362 (1938); R. Westerfield, Money, Credit and Banking 922 (1938). See also F. Farnsworth \& J. Honnold, Cases and Materials on Commercial Law 388-89 (2d ed. 1968); W. WELFING, supra note 40, at 139-40. It seems apparent that the section 3(a)(3) exemption was in general designed to avoid interference with short-term instruments issued to finance individual transactions in the ordinary course of business, with which banks are intimately involved. Most of the commercial paper in current use does not fit this description.

167 E.g., Ballantine's LaW Dictionary 988 (3d ed. W. ANDERson 1969); F. Moore, The Cyclopedic LaW Dictionary 872 (3d ed. 1940).

168 P. WYGKoff, Dictionary of Stock MARKeT Terms 203 (1964).

169 See text and notes at notes 103, 111 supra. The mere use of the word "prime" in describing commercial paper would suggest the possibility that some paper may exist that is not prime. Rhoades, The Secondary Banking System, 46 ROBERT MORRIS Associates BuLL. 150 (1963).

170 Interviews, supra note 5. See generally text and notes at notes 62-66 supra. In July, 1970, for example, Merrill Lynch, Pierce, Fenner \& Smith, Inc. announced that it had eliminated a requirement that the commercial paper that it underwrites and markets be rated "prime" by the National Credit Office. Wall Street Journal, July 30, 1970, at 3, col. 4. 
registered is subject to serious criticisms. From one perspective, conclusive proof that an issue of commercial paper is not "prime" can be obtained only when the issuer is unable either to roll over or to refinance the paper. Even if one recognizes that no paper is absolutely "prime," an attempt to grade commercial paper on a relative scale of "primeness" still confronts the problem of defining the relevant factors. ${ }^{171}$ Widespread disagreement among rating services and dealer credit departments concerning the basic creditability of commercial paper issuers reflects the present conceptual confusion among experts in the area. ${ }^{172}$ Important considerations, such as the liquidity of the issuer, have occasionally been ignored by the rating services. ${ }^{173}$ If "prime quality" is to constitute a meaningful standard, then better guidance must be provided in applying the concept. At present, to utilize "prime quality" as a precondition for exemption from registration appears to be a rather impractical and unsatisfactory endeavor.

2. Current Transactions. The "current transactions" concept was initially defined in 1935 when the section 3(a)(3) exemption was first applied to short-term collateral trust notes issued by finance companies. ${ }^{174}$ Superseding an earlier contrary opinion, ${ }^{175}$ the SEG stated in Securities Act Release No. 401 that "current transactions" by finance companies might properly include (1) the making of loans on, or the purchase of, notes, installment contracts or other evidences of indebtedness in the usual course of business, or (2) the payment of outstanding notes exempted under section 3(a)(3). ${ }^{176}$ In Securities Act Release No. 4412, the SEC in 1961 referred to the items covered by Release No. 401 as "composed of assets easily convertible into cash and . . comparable to liquid inventories of an industrial or mercantile company."177 Concerning the general applicability of the concept of "current transactions," the SEC required in Release No. 4412 that exempted paper be "issued to facilitate well-recognized types of current operational business requirements."178 The SEC then offered a definition in the negative to supplement this requirement:

the current transactions standard is not satisfied where the proceeds are to be used for the discharge of existing indebtedness

171 It does not appear that commercial paper ratings can be relied on to define which paper is "prime quality." See text at notes 95-96, 98, 106 supra.

172 Interviews, supra note 5; see, e.g., notes 66, 121 supra.

173 See, e.g., text at notes 105-06 supra.

174 See note 6 supra.

175 Securities Act Release No. 388 (June 8, 1935).

176 Securities Act Release No. 401 (June 18, 1935).

177 Securities Act Release No. 4412 (Sept. 20, 1961).

178 Id.; see text at note 147 supra. 
unless such indebtedness is itself exempt under section 3(a)(3); the purchase or construction of a plant; the purchase of durable machinery or equipment; the funding of commercial real estate development or financing; the purchase of real estate mortgages or other securities; the financing of mobile homes or home improvements; or the purchase or establishment of a business enterprise. ${ }^{179}$

The meaning of "current transactions" has been most explicitly defined in the context of the issuance of short-term paper by utilities. For many years there had been a question whether utilities, which can possibly have negative working capital, could issue commercial paper in compliance with the "current transactions" requirement. Since 1963, the SEG has agreed that utilities satisfy the criterion if issues are limited to a stated proportion of receivables, fuel supply, annual gross receipts, depreciation, or some combination of these amounts. ${ }^{180}$ This dilution of the "current transactions" concept in the utilities area is characteristic of its general misapplication in the commercial paper market.

In the 1920s and 1930s, commercial paper was a self-liquidating instrument that was used to finance the current operational expenditures of industry. ${ }^{181}$ It was the theory at the time that industrial paper was self-liquidating, whereas finance company paper was not. ${ }^{182}$ This theory was reflected in the discountability regulations of the Federal Reserve Board, and it was not until October, 1937 that the collateral-trust notes of finance companies became eligible for discount at Federal Reserve banks. ${ }^{183}$ In order to meet the "current transactions" prescription of

179 Securities Act Release No. 4412 (Sept. 20, 1961).

180 The first such formula was contained in a "no-action" letter to Goldman, Sachs \& Co. dated November 13, 1963 permitting an electric utility to have commerical paper outstanding in a dollar amount not to exceed (1) the dollar amount of receivables arising from the sale of electricity and appliances plus (2) the dollar amount of its fuel supply. Based on this precedent, other types of utilities have received "no-action" letters setting forth similar formulas. Address by Richard B. Dunn, Vice-President and General Counsel, New England Electric System, Edison Electric Institute Legal Committee Meeting, April 22, 1968, at 6 (copy on file at The University of Chicago Law Review); see Eggelston, Short-Term Financing Through Commercial Paper, PUB. UTu. ForT., May 23, 1968, at 27, 30. "No-action" requests and replies were not made public until the SEC adopted a proposal on October 29, 1970 to make public "no-action" requests and replies for requests received after December 1, 1970. SEC Securities Act Release No. 5098 (Oct. 29, 1970). See generally Lowenfels, SEC "No-Action" Letters: Some Problems and Suggested Approaches, 71 CoLUM. L. REv. 1256 (1971).

181 R. Foul.kE, supra note 1, at 3-4; Steiner, supra note 1, at 924; see text at note 9 supra.

182 N. BAXTER, supra note 1 , at 10 n.17.

183 Id. at 20. 
the 1933 Act, companies were advised to segregate completely funds obtained from financing by means of commercial paper in order to establish proof that the funds were to be used for immediate obligations rather than for long-term programs. ${ }^{184}$

At present, almost every conceivable type of manufacturing, mercantile, utility, and finance company is represented in the commercial paper market for purposes far afield from the nature of the instrument ${ }^{185}$ for which the section $3(a)$ (3) exemption was created..$^{186}$ The continuous rollover of the paper ${ }^{187}$ violates the original premise of the market - that it be used to provide financing of a current nature for normally self-liquidating transactions. ${ }^{188}$ During the market's boom in the late 1960s and early 1970, for example, issuers were financing longterm programs, including acquisitions, with short-term funds. ${ }^{189}$

Moreover, the "current transactions" criterion no longer provides a viable prerequisite for determining the eligibility of an issue of commercial paper for an exemption under section 3(a)(3). The concept of a short-term loan can easily be lost sight of in the current market. ${ }^{180}$ Due to the virtual impossibility of tracing funds, the "current transactions" standard becomes difficult to apply. ${ }^{101}$ Particular sources of funds can almost never be traced to particular working capital or fixed capital uses. Commingling of funds resulting from diversifications or mergers makes tracing even more difficult. ${ }^{192}$

3. Discountability at a Federal Reserve Bank. Member banks of the Federal Reserve System may borrow from a Federal Reserve bank

184 J.K. LAsser \& J.A. Gerardi, Federal. Securtites Act Procedure 54 (1934).

185 The Commercial Paper Market in 1970, supra note 72, at 26 (based on remarks by J. Russell Hanson, Vice-President of the First National Bank of Chicago); Interviews, suspra note 5. On December 16, 1970, the First Chicago Corporation, of which the First National Bank of Chicago is a wholly owned subsidiary, requested a "no-action" letter from the SEC for the issuance without registration of commercial paper in denominations of not less than one hundred thousand dollars, the proceeds of which were to be used to make interim construction loans, with loan commitments of up to three years, to borrowers intending to use the funds to purchase real estate and to finance the construction of income-producing property. The request stated an understanding that such use of proceeds was consistent with the "current transactions" concept of section 3(a)(3). Given these facts, the SEC replied that it would take no action if the paper were not registered, CCH 1971 FED. SEC. L. REP. I 78,010.

186 See text at notes $142-45$ supra.

187 See text at note 7 supra.

188 McGillicuddy, supra note 7.

180 Interviews, supra note 5; see text at notes 81, 87 supra; note 102 supra.

190 McGillicuddy, supra note 7, at 3-4.

191 Interviews, supra note 5.

192 Cloos, supra note 4 , at 14. 
either by rediscounting ${ }^{193}$ short-term commercial, industrial, agricultural, or other business paper or by giving their own promissory notes, secured by paper eligible for discounting, government securities, or other satisfactory collateral. Borrowings by the first method are known as discounts and by the latter method as advances. Both types of Federal Reserve bank lending are referred to as the discount mechanism. ${ }^{194}$ Commercial paper may be discounted if it meets the Federal Reserve Board's eligibility requirements, which are set forth in Regulation A. ${ }^{195}$ The interpretation accorded the phrase "current transactions"196 closely resembles these criteria.

When first enacted in 1913, the Federal Reserve Act ${ }^{197}$ was based on the concept that Federal Reserve bank credit should not be used to promote speculative or investment activity. ${ }^{198}$ Through the early 1930s, the Federal Reserve Board limited eligibility requirements to shortterm, self-liquidating commercial paper in an attempt to confine credit extended by member banks to short-term productive uses. ${ }^{199}$ Since the commercial paper currently being used is continuously rolled over and often used for financing long-term investments, ${ }^{200}$ it does not in general conform to the concept of discountability of commercial paper as it was understood when the section 3(a)(3) exemption of the 1933 Act was drafted.

193 Rediscounting is the process by which a Federal Reserve bank discounts for a member bank paper that the member bank has previously discounted for its customers. F.L. GARCLA, supra note 6, at 632; L. RUFENER, supra note 166, at 512.

194 U.S. Board of Governors of the Federal, Reserve System, The Federal ReSERVE SYSTEM 40 (5th ed. 1967).

19512 C.F.R. \$ 201 (1970). The relevant eligibility requirements of Regulation A provide in substance that a Federal Reserve bank may discount for a member bank a negotiable note, draft, or bill of exchange bearing the endorsement of a member bank, id. $\S 201.3(\mathrm{a})(\mathrm{l})$, that has a maturity not exceeding ninety days (except agricultural paper, which may have a maturity of up to nine months), id. § 201.3(a)(4); that has been issued or drawn, or the proceeds of which are to be used in producing, purchasing, carrying, or marketing goods or in meeting current operating expenses of a commercial, agricultural or industrial business, $i d$. $\S 201.3(\mathrm{a})(\mathrm{l})$; and that is to be used neither for permanent or fixed investment such as land, buildings, or machinery, id. \& 201.3(a)(2), nor for speculative transactions or transactions in securities (except direct obligations of the United States government), id. § 201.3(a)(3).

196 See text at notes 174-84 supra. See also text and notes at notes 142-45 supra.

197 Act of Dec. 23, 1913, ch. 6, 38 Stat. 251 (now 12 U.S.C. $\S \S 221$ et seq. (1970)).

198 C. Anderson, Evolution of the Role and Functioning of the Discount MechanISM 5, 20 (1966); see T. Mayer, Monetary Policy in the United States 30 \& n.10 (1968); note 145 supra.

199 C. ANDERSON, supra note 198, at 21-22, 30, 32, 5I; T. MAYER, supra note 196, at 30; R. WESTERFIELD, supra note 166 , at $652-56$. During the 1920 s, it was the predominant view that confining bank credit to short-term productive uses was the means to achieve economic stability and would automatically result in the proper volume of credit. C. ANDERson, supra note 198, at 21.

200 See text at notes 7, 81, 87 supra; note 102 supra. 
Moreover, discountability is no longer a suitable criterion by which to determine the applicability of the exemption to commercial paper. Over the last forty years, the Federal Reserve System has departed significantly from the principle that Federal Reserve bank credit should be extended only on the basis of short-term, self-liquidating commercial paper, ${ }^{201}$ and the concept of eligibility has been diluted to reflect this development. Eligibility requirements under Regulation A were expanded in 1937 to include, among other instruments, paper issued by the increasingly important finance companies. ${ }^{202}$ When Regulation A was again redrafted in 1955, no intention was expressed to structure the discount policy to limit the final uses of Federal Reserve bank credit to short-term productive purposes. ${ }^{203}$ Experience had demonstrated that the type of paper offered for discount afforded no indication of the specific uses a member bank was to make of the proceeds because the loan was to cover a reserve deficiency that had already occurred and that was generally the result of a large number of transactions. ${ }^{204}$ In addition, banks have not discounted eligible paper for several years, but instead have usually borrowed on their own promissory notes secured by government securities. ${ }^{205}$ Furthermore, since the standards of eligibility of commercial paper for discounting are largely the same as the "current transactions" notion, ${ }^{206}$ the impracticalities associated with that concept as a precondition for the exemption of section $3(\mathrm{a})(3)$ are also to be taken into account in appraising the discountability criterion. ${ }^{207}$ When these factors are considered, it becomes evident that the appropriateness of the discountability criterion as a requirement

201 C. ANDERSON, supra note 198 , at 50-51. The departures over the last forty years from this principle have in part prompted a recommendation to Congress by the Federal Reserve Board in 1963 that the present eligibility requirements be repealed and that emphasis be placed on the soundness of the paper offered and the appropriateness of the purposes for which member banks borrow. Id. at 49-51. No action has been taken on the proposal. For other recently proposed changes in the discount mechanism, see D. JoNEs, A ReView of Recent AGademic Literature on the Discount Mrchanism 25-36 (1968).

202 N. BAXTER, supra note 1, at 20; R. WESTERFIEID, stupra note 166, at 656. See also C. ANDERSON, supra note 198, at 33.

203 G. ANDERSON, supra note 198, at 49. Appropriate and inappropriate uses of the discount windows were, however, discussed during the revision of Regulation A. Id. at 48-49. See generally B. ShUL, Rationale and ObJEctives of the 1955 Revision of ReguIATION A (1966).

204 C. ANDERSON, supra note 198 , at 22, 28, 50-51.

205 T. MAYER, supra note 198, at 30; Interviews, supra note 5. Banks only occasionally secure their borrowing by eligible paper; it is usually more convenient to use government securities. T. MAYER, supra note 198, at 30; Interviews, supra note 5; see G. McKinney, JR., The Federal Reserve Discount Window 64-71 (1960). Some, however, see a revival of the use of eligible paper to secure borrowing. T. MAYER, supra note 198, at 31; Interviews, supra note 5.

206 See note 195 supra.

207 See text at notes 185-92 supra. 
for the exemption of commercial paper from the full coverage of the 1933 Act is seriously impaired.

4. Not Marketed to General Public. The objective of the 1933 Act was to insure that the process of distributing securities to the general public would be accompanied by registration of the securities and full disclosure of information relating to the underlying investment.208 An exemption from the disclosure provisions of the 1933 Act was provided for commercial paper because in the 1930s the paper was not sold to the "public," but only to banks. ${ }^{209}$ In contrast, a wide variety of corporate investors currently participate in the commercial paper market, and the paper is becoming increasingly attractive to private investors. ${ }^{210}$ Inherent in the 1933 Act's purpose was the prevention of just such widespread sales to the investing public without the protections afforded by disclosure. ${ }^{211}$

Moreover, unlike the criteria of "prime quality," "current transactions," and "discountability," the requirement that the paper be of a type not intended to be marketed to the general public remains a viable standard for determining eligibility under the section 3(a)(3) exemption. ${ }^{212}$ It is both reasonable and practical to adopt the principle that when commercial paper is offered to the public, the blanket exemption of section 3(a)(3) should no longer be applicable. ${ }^{213}$

208 See, e.g., SEC v. Ralston Purina Co., 346 U.S. 119, 124 (1953); Message of President Roosevelt to Congress, March 29, 1933, 77 CoNG. REc. 937, 954 (1933).

209 See text at notes 39-43, 143-46, 154-55, 164-66 supra.

210 See text at notes $48-57$ supra.

211 See materials cited note 208 supra. In 1957, the SEC's New York Regional Administrator brought an action to enjoin the sale of unregistered securities by a corporation that had made an offering of nine-month notes in denominations of one hundred, five hundred, and one thousand dollars to finance the promotion of various real estate ventures. The SEC charged that such a widespread sale of securities to the investing public in order to provide capital for a business venture without registration under the 1933 Act was in violation of the Act. The case became moot when the defendant registered. SEG v. Sire Plan, Inc., Litigation Release No. 1061 (S.D.N.X. 1957).

The SEC again dealt with the subject of "sale to the general public" in 1971 when counsel for Delaware Valley Realty and Mortgage Investors, a common law business trust that intended to qualify as a real estate investment trust in 1972, sought a "no-action" letter for the sale of its commercial paper without compliance with the 1933 Act's registration requirements. The notes were to be sold in multiples of five hundred dollars to existing stockholders of the company's parents. The proceeds were to be used to purchase consumer discount notes carrying maturities of up to forty-eight months. In denying the request, the SEC cited as reasons the small denominations of the securities, the "unsophisticated" character of the offerees, and the proposed use of the proceeds. BNA SEC. REG. \& L. REP. No. 104, June 2, 1971, at C-1.

212 Such a concept is familiar to the regulation of securities in determining the applicability of the private offering exemption of section 4(2) of the 1933 Act. See text at notes 225-32 infra; cf. People v. Walberg, 263 Cal. App. 2d 286, 69 Cal. Rptr. 457 (1968).

213 In connection with the explanation of the House Report on the 1933 Act that the section 3(a)(3) exemption applies to paper of a type "which rarely is bought by private 


\section{Regulation Under the 1933 Act}

The expanded uses of commercial paper in the current market make it apparent that the reasons put forth in 1933 for an exemption from registration are no longer persuasive. Assuming that the 1933 Act's disclosure philosophy continues to be sound, ${ }^{214}$ it is both inconsistent and unjustifiable to permit commercial paper to remain outside the full coverage of the Act.

While incursions upon the present regulatory structure are demanded by the current commercial paper market, the weighing of the relative advantages of various changes in the regulatory scheme for commercial paper must take into consideration the degree of impairment of the principal attraction of commercial paper for the issuerits low cost in relation to the amount of money that can be raised quickly and efficiently. To subject commercial paper to registration for each issue would virtually rule out its use.215 Because of the need to adjust the terms and amounts of each offering to rapidly changing market conditions, the time required for full registration of each issue would be prohibitive. ${ }^{210}$ In attempting to preserve commercial paper as a valuable source of credit, one can approach the problem of the market's regulation under the 1933 Act in several ways.

One suggestion that has been advanced is to exempt from registration short-term notes in amounts above a large minimum denominationfor example, one hundred thousand dollars. ${ }^{217}$ The underlying theory

investors," see text at notes 148-49 supra, Professor Loss suggests that limiting the section $3(a)(3)$ exemption to paper that is "privately offered" would make it redundant in view of the nonpublic offering exemption of section 4(2). $1 \mathrm{~L}$. LOSs, SECURITIES Regulation 567 (2d ed. 1961, Supp. 1969). While there may be some overlap between the two exemptions, instruments of a type rarely bought by "private investors" will not, however, necessarily be involved in "transactions by an issuer not involving any public offering," either as these concepts were understood by the drafters of the 1933 Act or as they are currently interpreted.

214 The efficacy of the basic concept of disclosure in the regulation of corporate securities is the subject of a distinct controversy not within the scope of this comment. For critical analyses of the disclosure philosophy, see H. MANNE, INSDDER TRADING AND THE StOCK MARKET (1966); Douglas \& Bates, The Federal Securities Act of 1933, 43 YAlE L.J. 717 (1933); Morton \& Booker, The Paradoxical Nature of Federal Securities Regulations, 44 DENVER L.J. 479 (1967); Stigler, Public Regulation of the Securities Markets, 37 J. Bus. 117 (1964). But see L. BRANDEIS, OthER PEOPLE's MONEY (1933), reprinted from HARPER's WEERIY, 1913-14; SEC, Disclosure to INvestors (1969); Cary, Corporate Standards and Legal Rules, 50 GArIF. L. REv. 408 (1962); Knauss, A Reappraisal of the Role of Disclostre, 62 Mich. L. Rev. 607 (1964); Wheat, "Truth in Securities" Three Decades Later, 13 How. L.J. 100 (1967). See also SEC, Statement of the Securities and Exchange Commission on the Future Structure of the Securities Market, Feb. 2, 1972.

216 Compliance with the prospectus requirements of sections $5(b)$ and 10 of the 1933 Act poses no burdens peculiar to the commercial paper market. Interviews, supra note 5 . 216 Cloos, supra note 4, at 13; Liquidity Fears Crease the Paper Market, supra note 97; Interviews, supra note 5 .

217 Federal Securities Code $\$ \$ 216 \mathrm{~A}, 301(\mathrm{n})$ \& Comments 1-5 (Tent. Draft No. 1, 1972); 
is that one who can afford to purchase paper in this large amount is presumably so sophisticated an investor that the protections of the 1933 Act are unnecessary. Such a limitation, however, would not be in keeping with the congressional purposes of full disclosure of information to all investors. Potential purchasers of commercial paper who might very well need the protections afforded by registration would be required to make investment decisions without access to the information essential to comprehensive judgments. ${ }^{218}$

More in accord with the purposes of the 1933 Act would be to provide some form of "shelf registration" procedure for commercial paper -that is, the procedure by which a security is permitted to be registered even though it is not intended to be marketed to the public immediately after the registration statement is declared effective. ${ }^{219}$ Paper registered "for the shelf" could be offered over an appropriate period of time, perhaps one year. Posteffective amendments to the registration statement would be employed to update information about the commercial paper issuer and to specify the amounts, terms, uses of the proceeds, ${ }^{220}$ and other data for each offering. ${ }^{221}$

The registration of commercial paper for deferred distribution would accommodate the special needs of the market while insuring investors both a reasonably current flow of information about the market's borrowers $^{222}$ and the enjoyment of more comprehensive rights of action against the issuer and the vendor. ${ }^{223}$ Moreover, such a registration scheme would further streamline the commercial paper market by sifting out of the market those marginally healthy companies that could not survive the light of disclosure. ${ }^{224}$

Interviews, supra note 5 . Another approach is to combine this denominational limitation with the requirement that the exemption be further confined to companies that also report under the Securities Exchange Act of 1934 (sections 12 and 13, 15 U.S.C. $\S \S 78 l-m(1970))$. Id. While this additional prerequisite to an exemption is appropriate in light of the current promotion of coordinated disclosure under the 1933 and 1934 Acts, see, e.g., SEC, Disclosure To INVESTORs (1969); Cohen, "Truth in Securities" Revisited, 79 HARv. L. REv. 1340 (1966), it would not provide the complete disclosure necessary in each issue of commercial paper by every issuer, see text at notes 218-24 infra.

218 See 1 SEG, Discrosure to INvestors 10, 46 (1969); H.R. REP. No. 85, 73d Cong., Ist Sess. 8 (1933); cf. cases cited note 267 infra.

218 This procedure is thoroughly discussed in Hodes, Shelf Registration: The Dilemma of the Securities and Exchange Commission, 49 VA. L. REv. 1106 (1963). For more concise treatments, see 1 L. Loss, supra note 213, at 296-300, 537-38, 685-86; R. JENNincs \& H. Marsh, Securtites Regulation: Cases and Materials 201-04 (1968).

220 Disclosure of uses to be made of the proceeds of an issue of commercial paper is an important item of information not revealed elsewhere. See text at notes 87, 181-92 supra; note 84 supra.

221 See Hodes, supra note 219, at 1107.

222 Interviews, supra note 5. See also text at notes 96-99 supra.

223 See text and notes at notes 134, 138 supra.

224 Interviews, stipra note 5 . 
The removal of the section 3(a)(3) exemption would not, of course, affect the eligibility of commercial paper for the exemption provided in section 4(2) of the 1933 Act for "transactions by an issuer not involving any public offering." 225 While the applicability of the private offering exemption turns on a consideration of "all the surrounding circumstances,"226 the issuance of both dealer and direct paper can qualify as a private offering in certain circumstances. ${ }^{227}$ In the case of dealer paper, even though the dealer purchases the paper with the intent to resell it, the entire two-step transaction can still constitute a private offering if the offerees do not include members of the general public. On the other hand, if the dealer engages in a distribution, a term that the SEC has tended to equate with a public offering, what may begin as a private offering can proliferate into a two-step public offering, and the dealer may be liable as an "underwriter" under section 2(11) of the 1933 Act. ${ }^{28}$ In the case of direct paper, similar problems of leakage in the private offering are involved. ${ }^{229}$ Due to both the vague criteria of the private offering exemption and the tremendously varied marketing practices among dealers and direct issuers, a comprehensive consideration of the applicability of the exemption for the commercial paper market would not be practical here. ${ }^{230}$ Since the exemption is directed to activities in the offering of securities "where there is no practical need for [the application of the registration requirements] or where the public benefits are too remote,"231 the adaptation, to whatever extent necessary, of the practices of the commercial paper market to the private offering exemption could prove fruitful to its participants. As the market continues to expand and to diversify,

225 General discussions of this exemption for nonpublic offerings are found in $\mathbf{R}$. JENnINGS \& H. MARSH, supra note 219, at 368-71; 1 L. Loss, supra note 213, at 653-65; Israels, Some Commercial Overtones of Private Placement, 45 VA. L. REv. 851 (1959); Orrick, Non-Public Offerings of Corporate Securities-Limitations on the Exemption Under the Federal Securities Act, 21 U. PrTT. L. REv. 1 (1959); Victor \& Bedrick, Private Offering: Hazards for the Unwary, 45 VA. L. REv. 869 (1959).

2261 L. Loss, supra note 213, at 654.

227 Two important discussions of the requirements for the exemption are SEC $v$. Ralston Purina Co., 346 U.S. 119 (1953), and Securities Act Release No. 285 (Jan. 24, 1935).

22815 U.S.C. $\& 77 \mathrm{~b}(11)$ (1970); R. JENNINGS \& H. MARSH, supra note 219, at 368; see Orrick, Some Interpretative Problems Respecting the Registration Requirements Under the Securities Act, 13 Bus. LAw. 369-72 (1958). The exemptions provided by other subsections of section 4 are inapplicable to transactions in dealer paper because of various practices in that sector of the market.

229 See R. JENNINGS \& H. MARSH, sufra note 219, at 368.

230 Such a consideration is also complicated by the very loose practices that have developed in recent years in the application of the self-administered private placement exemption. Id. at 371. Indications are, however, that the private offering exemption would not be very useful to the current market. Interviews, supra note 5 .

231 H.R. REP. No. 85, 73d Cong., 1st Sess. 5 (1933). 
however, resort to the private offering exemption becomes increasingly difficult.

\section{The Securities Exchange Act of 1934}

In its definition of the term "security," section 3(a)(10) of the Securities Exchange Act of $1934^{232}$ excludes from the coverage of the Act notes with an original maturity of less than nine months. ${ }^{233}$ If a security falls within the definition of section $3(a)(10)$, investor protection is afforded by provisions that include liabilities for fraud, ${ }^{234}$ registration for brokers and dealers, ${ }^{235}$ liability for misleading statements, ${ }^{236}$ and investigation and prosecution powers of the SEC. ${ }^{237}$ Since it has a maturity of less than nine months, commercial paper appears to be expressly excluded from the definition of a "security" under the terms of section $3(a)(10)$. When the economic realities of the current commercial paper market are considered, however, it becomes difficult to justify the failure to provide the same protections to investors in commercial paper that the 1934 Act affords to investors in other types of nonequity securities. 238

\section{A. Section 3(a)(10) and Plain Meaning}

Recent judicial discussions have approached the problem of defining the scope of the exclusionary provision of section $3(a)(10)$ in terms of the "plain meaning" principle of statutory interpretation. ${ }^{239}$ In essence,

232 Securities Exchange Act of 1934, § 3(a)(10), 15 U.S.C. \$78c(a)(10) (1970).

233 Section 3(a)(10) excludes from the definition of a "security" for the purposes of the Act "any note, draft, bill of exchange, or banker's acceptance which has a maturity at the time of issuance of not exceeding nine months, exclusive of days of grace, or any renewal thereof, the maturity of which is likewise limited."

234 Securities Exchange Act of 1934, § 10(b), 15 U.S.C. § 78j(b) (1970), and SEC Rule 10b-5, 17 C.F.R. \& 240, 10b-5 (1970), promulgated thereunder; Securities Exchange Act of 1934, § 15(c)(1), 15 U.S.C. § 78o(c)(1) (1970); id. § 20, 15 U.S.C. § 78t (1970).

235 Securities Exchange Act of 1934, § 15(a)(1), 15 U.S.C. § 78o(a)(1) (1970). Both sections $15(a)(1)$ and $15(c)(1)$ contain language including within their coverage "any security (other than an exempted security or commercial paper, bankers' acceptances, or commercial bills)." There is no explanation in the legislative history for such phrasing. It may be assumed that the language is merely a specific enumeration of certain instruments meant to be excluded from the definition of a "security" in section $3(a)(10)$.

$236 I d . \S 18,15$ U.S.C. § 78r (1970).

$237 \mathrm{Id} . \S 17,15$ U.S.C. $\$ 78 \mathrm{q}(1970) ;$ id. $\$ 21,15$ U.S.C. $\$ 78 \mathrm{u}$ (1970).

238 Sanders v. Nuveen, Civil No. 70 C 597 (N.D. III., Nov. 18, 1970), appeals docketed, Nos. 71-1163, 71-1164, 7th Gir., Feb. 26, 1971, is before the Seventh Circuit on the question whether the holder of commercial paper on which there has been a default is protected by the 1934 Act. The district court, without rendering an opinion, denied a motion to strike the claims under the 1934 Act. Argument was heard by the Seventh Circuit on January 26, 1972. See also notes 53, 111 supra.

239 These discussions were all at the district court level. Investment Properties Int?, 
the rule provides that where the statute is clear and unambiguous and a literal reading does not give rise to absurd or mischievous consequences or thwart a manifest purpose, courts shall base their decisions on this reading alone. ${ }^{240}$ It is clear, however, that while the courts in these recent cases have claimed to construe the exclusionary provision of section 3(a)(10) according to its express language, they have in fact demonstrated a willingness to seek the assistance of legislative intent in light of commercial realities. ${ }^{241}$ Greater reliance on the legislative history as an aid to statutory interpretation has gradually eroded the former rigidity of the "plain meaning" rule. ${ }^{242}$ This expanded search for the "fair construction"243 of a statute is particularly appropriate in the application of section $3(a)(10)$ to commercial paper because the 1934 Act is presently confronted with circumstances not contemplated at the time of its passage. ${ }^{244}$ The evolution of the commercial paper market demands that the exclusionary provision no longer be taken on its face as the sole evidence of legislative intent. A construction of that clause must be compatible with the broad purposes of the 1934 Act and the commercial realities of the market. ${ }^{245}$

\section{B. Toward a Construction of Section 3(a)(10)}

There is no explanation in the legislative history of the 1934 Act for the exclusionary provision of section $3(a)(10)$. The only distinction be-

Ltd. v. I.O.S., Ltd., CCH 1972 FED. SEC. L. REP. I 98,011, at 90,789 (S.D.N.Y. Apr. 21, 1971); Movielab, Inc. v. Berkey Photo, Inc., 321 F. Supp. 806, 809 (S.D.N.Y. 1970), aff'd per curiam, 452 F.2d 662 (2d Cir. 1971); Superintendent of Ins. v. Bankers Life \& Cas. Co., 300 F. Supp. 1083, 1100 (S.D.N.Y. 1969) (dictum), aff'd, 430 F.2d 355 (2d Gir. 1970), rev'd, 404 U.S. 6 (1971); SEC v. Fifth Ave. Coach Lines, Inc., 289 F. Supp. 3, 38 (S.D.N.Y. 1968). See also G.A.F. Corp. v. Milstein, 324 F. Supp. 1062 (S.D.N.Y. 1971).

240 For treatments of the "plain meaning" rule of statutory construction, see Frankfurter, Some Reflections on the Reading of Statutes, 47 ColuM. L. Rev. 527 (1947); Jones, The Plain Meaning Rule and Extrinsic Aids in the Interpretation of Federal Statutes, 25 WASH. U.L.Q. 2 (1939); Note, $A$ Re-evaltation of the Use of Legislative History in Federal Courts, 52 CoLUm. L. REv. 125 (1952); Note, The Plain Meaning Rule in the Reflection of Current Trends and Proclivities, 26 TEMP. L.Q. 174 (1952).

241 Investment Properties Int'l, Ltd. v. I.O.S., Ltd., CCHI 1972 FED. SEC. L. REP. I 93,011, at 90,734-36 (S.D.N.Y. Apr. 21, 1971); Movielab, Inc. v. Berkey Photo, Inc., 321 F. Supp. 806, 809 (S.D.N.Y. 1970), affd per curiam, 452 F.2d 662 (2d Cir. 1971); Superintendent of Ins v. Bankers Life \& Cas. Co., 300 F. Supp. 1083, 1101 (S.D.N.Y. 1969), affd, 430 F.2d 355 (2d Cir. 1970), rev'd, 404 U.S. 6 (1971); SEC v. Fifth Ave. Coach Lines, Inc., 289 F. Supp. 3, 38 (S.D.N.Y. 1968), affd, 435 F.2d 510 (2d Cir. 1970). The instruments involved in these cases were essentially singular in number and were quite unlike commercial paper. 242 E. Farnsworth, AN INTROduction to THE LEGAL SySTEM OF THE UNITED STATES 72-73 (1963); Landis, Statutes and the Sources of Law, 2 HARv. J. LEGIS. 7, 13 (1965), reprinted from HARVARd LEgal Essays (R. POUND ed. 1934); see materials cited note 240 supra.

243 Frankfurter, supra note 240, at 545.

244 See Llewellyn, Remarks on the Theory of Appellate Decision and the Rules or Canons About How Statutes Are to Be Construed, 3 VAND. L. REv. 395, 400 (1950).

245 See id. at 401. 
tween this exclusionary language and the exemption provided in section 3(a)(3) of the 1933 Act is the omission in the former of the phrasing, "which arises out of a current transaction or the proceeds of which have been or are to be used for current transactions." This distinction is reflected in the cautious treatment that Professor Loss accords the relationship between the two sections: "Short-term notes of the type which are exempted from registration under the Securities Act by Section 3(a)(3) are excluded from the definition of 'security' in the Exchange Act [section 3(a)(10)]."246

Reference to the legislative history of the 1934 Act sheds no light on the importance or meaning of the difference between the two sections. The original draft of the 1934 Act, introduced in the Senate on February $9,1934^{247}$ and in the House on February $10,1934,{ }^{248}$ provided no exclusion for short-term notes. H.R. 8720, introduced in the House on March 19, 1934, contained a definition of a "security" that by its terms excluded only those short-term obligations arising "out of a current transaction or the proceeds of which have been or are to be used for current transactions," 249 language identical to that used in section $3(a)(3)$ of the 1933 Act. After the "current transactions" phrasing was omitted and then restored in subsequent bills in the House ${ }^{250}$ and Senate, ${ }^{251}$ the reference to "current transactions" was deleted from the exclusionary language of the definition of a "security" in the final version of the 1934 Act. ${ }^{252}$ Since there is no legislative comment with respect to this deletion, it cannot be gainfully surmised whether the omission of the "current transactions" phrasing was an inadvertent mistake, an assumption on the part of the legislature that the clause was unnecessary, or a conscious attempt to distinguish section $3(\mathrm{a})(10)$ of the 1934 Act from section 3(a)(3) of the 1933 Act. ${ }^{253}$

The only judicial treatment of the relationship between the exclu-

2462 L. Loss, supra note 213 , at 796 (emphasis in original).

247 S. 2693, 73d Cong., 2d Sess. (1934). See also Hearings on S. Res. 84, S. Res. 56, and S. Res. 97 Before the Senate Comm. on Banking and Currency, 73d Cong., 2d Sess., pts. 15-16 (1934).

248 H.R. 7852, 73d Cong., 2d Sess. $\$ 3.10$ (1934). See also Hearings on H.R. 7852 and H.R. 8720 Before the House Comm. on Interstate and Foreign Commerce, 73d Cong., 2d Sess. (1934).

249 73d Cong., 2d Sess. § 3(2)(10) (1934). S. 3420, 73d Cong., 2d Sess. (1934) (introduced on April 20), the next securities bill to be considered, contained the "current transactions" language in section $3(a)(10)$.

250 H.R. 9323, 73d Cong., 2d Sess. \& 3(a)(10) (1934) (dated April 26).

251 H.R. 9323, 73d Cong., 2d Sess. \$ 3(a)(10) (1934) (Senate version).

252 Securities Exchange Act of 1934, § 3(a)(10), I5 U.S.C. $\S 78(c)(a)(10)$ (1934).

253 See generally H. BLACK, Construction AND INTERPRETATTON OF THE LAWs $\$ 105$ (2d ed. 1911). 
sionary language of section 3(a)(10) of the 1934 Act and the exemption of section 3(a)(3) of the 1933 Act is found in Anderson v. Francis $I$. $d u$ Pont \& Co. ${ }^{254}$ In that case, the defendant solicited money from the plaintiffs to invest in the commodities market with the guarantee that it would be returned to them at a profit. In return for their money, the plaintiffs received two promissory notes, one with a maturity of less than nine months. After holding that the transaction was in substance an investment contract cognizable as a "security" within the 1934 Act, the court said that even if the instruments in question were considered to be notes, one carrying a maturity of less than nine months, the exclusionary language of section $3(a)(10)$ would be inapplicable. The court's discussion is of interest:

The exclusionary language of Section 78c(a)(10) [section 3(a)(10) of the 1934 Act] is virtually identical to the language of section $3(a)(3)$ of the 1933 Act and applies to the same type of short-term notes as the 1933 Act. 2 L. Loss, Securities Regulation 797-98 (2d ed. 1961). Both these sections apply to "short-term paper of the type available for discount at a Federal Reserve bank and of a type which rarely is bought by private investors," 1 L. Loss, Securities Regulation 566-68 (2d ed. 1961), quoting H.R. Rep. No. 85, 73d Cong., lst Sess. 14 (1933). The notes involved in this case are clearly not of the type Congress intended to exclude from coverage. 255

What the court did in effect was to equate, without analysis, ${ }^{256}$ the interpretation of section $3(\mathrm{a})(3)$ of the 1933 Act with that of section $3(a)(10)$ of the 1934 Act. While it must be acknowledged that the court was not dealing specifically with commercial paper, the court did state that both sections apply to the same type of short-term notes and that the "discountability" and "private investor" concepts of the 1933 Act also apply to the 1934 Act. Since "current transactions" has been given virtually the same definition as "discountability," 257 it is only a short step to the adoption of the "current transactions" criterion in the interpretation of section $3(\mathrm{a})(10)$ of the 1934 Act.

When it is recalled that the "current transactions" concept was fundamental to the type of instrument that the Seventy-third Congress intended to isolate from the full investor protections of both federal

254291 F. Supp. 705 (D. Minn. 1968).

255 Id. at 708-09 (dictum).

256 With respect to the latter citation by the court to Loss, Professor Loss's reference is only to section 3(a)(3) of the 1933 Act and does not support the court's assertion of identity.

257 See text at notes 174-79 supra; note 195 supra. 
securities acts, ${ }^{258}$ the appropriateness of the court's approach in Anderson becomes evident. The construction of the exclusionary provision of section 3(a)(10) of the 1934 Act in terms of the legislative history of the section 3(a)(3) exemption of the 1933 Act is particularly proper in this instance because of the companion scope and aims of the two federal securities acts ${ }^{259}$ and because of the absence in the legislative history of an explanation for the exclusionary language of section $3(\mathrm{a})(10)$.

Moreover, consideration of the Supreme Court's decision in Tcherepnin v. Knight ${ }^{260}$ indicates that the inquiry into what constitutes a "security" need not be limited to the literal definition of the term in section $3(a)(10)$ of the 1934 Act. In that case, the Court held that a withdrawable capital share in a savings and loan institution is a "security" within the meaning of section $3(a)(10) .{ }^{261}$ In setting forth the groundwork on which it reached its conclusion, the Court, while not specifically concerned with the section's exclusionary provision, furnished two valuable guidelines for the construction of the section. First, since the 1934 Act is remedial legislation, the Act, and in particular the definition of a "security" in section $3(\mathrm{a})(10)$, should be given a broad interpretation in order to fulfill the purposes of the Act. Second, the term "security" should be defined with regard to substance rather than form and should emphasize economic reality. ${ }^{262}$ Applying the Court's reasoning in Tcherepnin to the realities of the commercial paper market, one finds it inconsistent to exclude commercial paper from the Act's coverage. Commercial paper has become a popular investment instrument for a diverse sector of the public. In accordance with the 1934 Act's purposes, the present usage and investment character of commercial paper should be recognized by its inclusion within the full provisions of the Act.

258 See text at notes 9, 142-45, 158-62, 181-84 supra.

259 See Tcherepnin v. Knight, 389 U.S. 332, 335-36 (1967). For discussions of this in pari materia canon of statutory construction, see H. BLACK, CoNSTRUCTION AND INTERPRETATION OF THE LAWs § 104 (2d ed. 1911); J. SutherLand, Statutory Construction $\S \S 443-18$ (2d ed. 1904). While the 1933 Act is concerned primarily with the protection of the investors through effective disclosure in the sale of new securities, one of the central purposes of the 1934 Act is the protection of the public in its financial investment in postdistribution trading on the over-the-counter market and the securities exchanges. 1 L. Loss, supra note 213, at 130-31. SEC v. Texas Gulf Sulphur Co., 401 F.2d 833, 858 .(2d Cir. 1968), cert. denied, 394 U.S. 976 (1968); H.R. REp. No. 1383, 73d Cong., 2d Sess. 11 (1933).

260389 U.S. 332 (1967).

261 Id. at 345.

$262 I d$. at 335-36. Even the form of commercial paper has changed to some extent. See note 6 supra. 


\section{Regulation Under the 1934 Act}

The principal ramification of the inclusion of commercial paper within the 1934 Act is the applicability of rule $10 \mathrm{~b}-5$ liabilities to the purchase and sale of the paper. While two of the antifraud provisions of the 1933 Act are applicable to commercial paper, ${ }^{263}$ neither is as farreaching as rule $10 \mathrm{~b}-5,{ }^{264}$ which, although little used in its early years, now generates as much litigation as all of the other general antifraud provisions of the federal securities acts taken together. ${ }^{265}$ Recent cases have expanded the protection of rule $10 \mathrm{~b}-5$ to include private corporate dealings, transactions that are much less amenable to the rule's coverage than commercial paper. ${ }^{268}$ To provide investors in commercial paper with the rights of redress under rule $10 \mathrm{~b}-5$ would merely grant the same important remedial protections that investors in other securities currently enjoy. ${ }^{267}$

\section{CONCLUSION}

Commercial paper has become a vital form of financing and a significant investment instrument. Whether the present inconsistencies in the market's regulatory aspects should be approached by legislative reform, ${ }^{268}$ administrative action, ${ }^{269}$ or close judicial scrutiny of the economic realities is a subject for further inquiry. ${ }^{270}$ What is in evi-

263 See text and notes at notes $129-30$ supra.

264 Rule $10 \mathrm{~b}-5$ is the most effective antifraud remedy of the federal securities acts because of its broad coverage of persons and transactions, absence of express defenses, and procedural advantages. A. BrombERG, SecuRtTiEs LAW: FraUd-SEG RuLE 10b-5 \$\$ 2.3(800), 2.5 (1971 ed.); W. GARY, CASES AND MATERIALS ON CoRporations 794-98 (4th ed. unabr. 1969). 265 A. BROMBERG, supra note 264 , at $\$ 2.5(6)$.

200 Superintendent of Ins. v. Bankers Life \& Cas. Co., 404 U.S. 6 (1971); Movielab, Inc. v. Berkey Photo, Inc., 452 F.2d 662 (2d Cir. 1971).

207 Assuming the basic soundness of the concept of protecting investors through antifraud remedies, the degree of financial expertise possessed by some participants in the commercial paper market should not deprive every investor of the overall availability of the remedies under the federal securities acts. See cases cited note 266 supra; Lehigh Valley Trust Co. v. Central Nat'I Bank, 409 F.2d 989 (5th Cir. 1969); SEC v. Texas GuIf Sulphur Co., 401 F.2d 833, 849 (2d Cir.), cert. denied, 394 U.S. 976 (1968); Johns Hopkins Univ. v. Hutton, 297 F. Supp. 1165,1217 (D. Md. 1968), affd, 422 F.2d 1124 (4th Cir. 1970). Professor Manne, however, has questioned many of the basic concepts involved. See $\mathrm{H}$. Manne, suppra note 214. But see W. PaInTER, Federal Regulation of Insider Trading (1968).

268 E.g., Federal Securities Code §§ 216A, 301(n) \& Comments 1-5 (Tent. Draft No. 1, 1972).

209 E.g., Schneider, Reform of the Federal Securities Laws, 115 U. PA. L. REv. 1023 (1967).

270 E.g., Tcherepnin v. Knight, 389 U.S. 332 (1967). 
dence is that the swift evolution of the commercial paper market has made a reshaping of the present regulatory structure essential to both the continued maturation of the market and the effective protection of the investor.

\section{ADDENDUM}

After this comment went to press, the Court of Appeals for the Seventh Gircuit held in Sanders $v$. Nuveen ${ }^{271}$ that commercial paper-specifically, promissory notes with a maturity not exceeding nine months that are offered to the public as an investment-is a "security" within the definition of that term in section 3(a)(10) of the Securities Exchange Act of $1934 .{ }^{272}$

Kenneth V. Handal

271 Nos. 71-1163, 71-1164 (7th Cir., June 9, 1972).

272 See also notes 53, 111, 238 supra. 